\title{
Legal Responses to Sexual Violence in Custody: State Criminal Laws Prohibiting Staff Sexual Abuse of Individuals under Custodial Supervision
}

\author{
Brenda V. Smith \\ American University Washington College of Law, bvsmith@wcl.american.edu \\ Jaime M. Yarussi \\ American University Washington College of Law
}

Follow this and additional works at: https://digitalcommons.wcl.american.edu/facsch_lawrev

Part of the Law and Gender Commons, Law Enforcement and Corrections Commons, and the Sexuality and the Law Commons

\section{Recommended Citation}

Smith, Brenda V. and Yarussi, Jaime M., "Legal Responses to Sexual Violence in Custody: State Criminal Laws Prohibiting Staff Sexual Abuse of Individuals under Custodial Supervision" (2009). Articles in Law Reviews \& Other Academic Journals. 886.

https://digitalcommons.wcl.american.edu/facsch_lawrev/886

This Article is brought to you for free and open access by the Scholarship \& Research at Digital Commons @ American University Washington College of Law. It has been accepted for inclusion in Articles in Law Reviews \& Other Academic Journals by an authorized administrator of Digital Commons @ American University Washington College of Law. For more information, please contact kclay@wcl.american.edu. 
legal

to sexual violence

in custody 


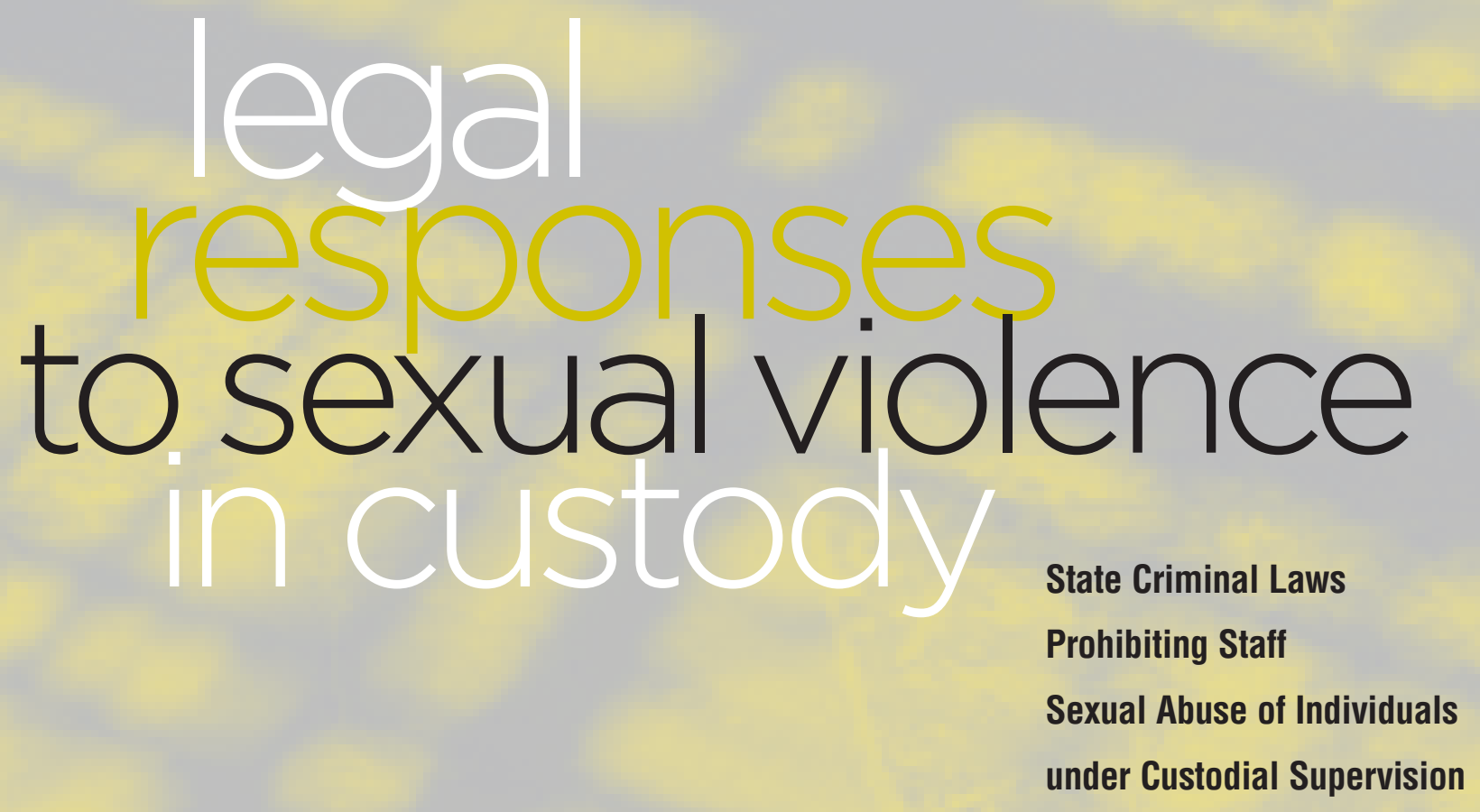

\section{AUTHORS:}

Brenda V. Smith, J.D.

Professor of Law

Director

NIC/WCL Project on Addressing Prison Rape

American University Washington College of Law

4801 Massachusetts Ave NW

Washington DC, 20016

Phone: 202-274-4261 Fax: 202-274-4182

bvsmith@wcl.american.edu
Jaime M. Yarussi, M.S.

Program Coordinator

NIC/WCL Project on Addressing Prison Rape

American University Washington College of Law

4801 Massachusetts Ave NW

Washington DC, 20016

Phone: 202-274-4385 Fax: 202-274-4373

jyarussi@wcl.american.edu 
Copyright (C) 2009 for the National Institute of Corrections by Brenda V. Smith and Jaime M. Yarussi

This publication was prepared under cooperative agreement 05S17GJE8 between the National Institute of Corrections, U.S. Department of Justice and American University, Washington College of Law. Points of view or opinions stated in this document are those of the authors and do not necessarily represent the official opinion or policies of the U.S. Department of Justice or American University Washington College of Law.

All rights reserved. No part of this publication may be produced or transmitted in any form or by any means, electronic or mechanical, including photocopy, recording, or any information storage or retrieval system, without permission in writing from the authors. Requests for permission to make copies of any part of this publication should be mailed to:

Professor Brenda V. Smith

The NIC/WCL Project on Addressing Prison Rape

American University

Washington College of Law

4801 Massachusetts Ave, NW

Washington, DC 20016 


\section{The National Institute of Corrections \\ 320 First Street, N.W. \\ Washington, D.C. 20534 \\ $1-800-995-6423$ or $202-307-3995$ \\ Fax: 202-307-3106 \\ www.nicic.org}

\section{Morris L. Thigpen}

Director

\section{Thomas Beauclair \\ Deputy Director}

\section{Chris Innes}

Chief, Research and Evaluation Division

\section{Dee Halley}

Correctional Program Specialist

Prof. Brenda V. Smith, J.D.

Project Director, WCL/NIC Project on Addressing Prison Rape

Jaime M. Yarussi, M.S.

Program Coordinator, WCL/NIC Project on Addressing Prison Rape 


\section{Acknowledgements:}

Legal Responses to Sexual Violence in Custody: State Criminal Lawes Prohibiting the Sexual Abuse of Individuals under Custodial Supervision is the end product of work by many organizations and individuals concerned about preventing and addressing sexual abuse of individuals under custodial supervision.

We would like to thank the many contributors and reviewers who have devoted their insightful and honest commentary. We also could not have completed this publication without the work of April Fehling. Finally, we would like to thank the staff of the National Institute of Corrections (NIC), Morris Thigpen, Director, Thomas Beauclair, Deputy Director,

Chris Innes, Chief, Research and Evaluation Division, and Dee Halley, Correctional Program Specialist, for supporting this important work. We also thank Larry Solomon, former Deputy Director of NIC whose steadfast support for work on addressing sexual violence in custody resulted in improved laws, policies and protection of persons in custody.

This publication builds on important work done by Prof. Brenda V. Smith in researching legal responses to sexual violence in institutional settings. Legal Responses to Sexual Violence in Custody: State Criminal Lawes Prohibiting the Sexual Abuse of Individuals under Custodial Supervision addresses rapidly developing areas of law and practice in the United States. The information in this publication is current as of August 2009. As law and policies rapidly change, we will remain abreast of those changes but encourage readers to contact us with new information as it becomes available. 


\section{Foreword}

In 1999, the American University, Washington College of Law (WCL) entered into a cooperative agreement with the National Institute of Corrections (NIC) to provide training to high level correctional decision makers on key issues in addressing and investigating staff sexual misconduct. With the enactment of the Prison Rape Elimination Act in 2003, WCL's focus shifted to addressing prison rape - both staff sexual misconduct with offenders and offender-on-offender sexual violence and abuse.

This publication is the first in a series that forms the basis of a legal "tool kit" of laws to address sexual violence against persons under correctional supervision. This publication as well as others in the tool kit are a critical part of NIC's response to its obligation to provide training, education, information and assistance under $\S 5$ of the Prison Rape Elimination Act of 2003. ${ }^{1}$

Although offender-on-offender sexual abuse is also a pervasive problem in U.S. correctional institutions, ${ }^{2}$ this publication will only address the issue of staff-on-offender sexual misconduct. Subsequent publications will address legal tools for addressing sexual violence between offenders.* 


\section{Table of Contents}

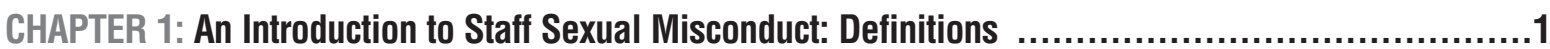

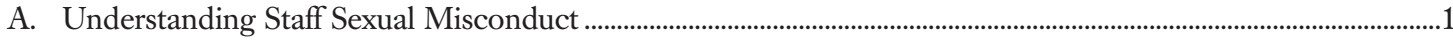

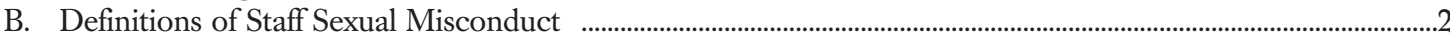

1. The Prison Rape Elimination Act of 2003

2. The Bureau of Justice Statistics

3. Federal Criminal Law

4. State and Local Agency Policy

5. State Criminal Law

CHAPTER 2: State Criminal Laws Coverage of Agencies and Personnel ................................5

A. Institutional Facilities and Personnel .........................................................................................................................

B. Community Corrections Agencies and Personnel ...............................................................................................................

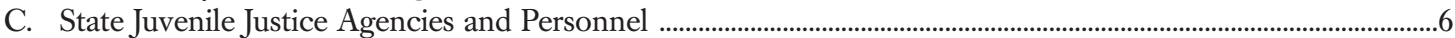

D. Private Facilities and Personnel .......................................................................................................................................

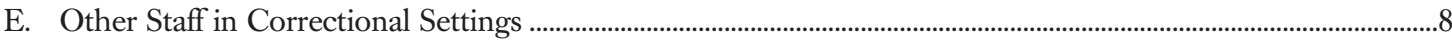

1. Contractors

2. Volunteers

3. Staff with Supervisory and Disciplinary Authority

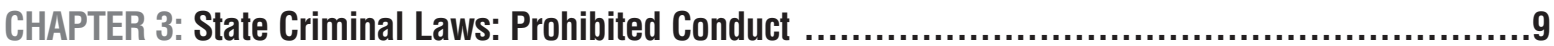

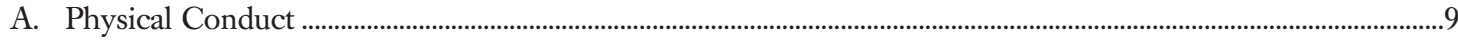

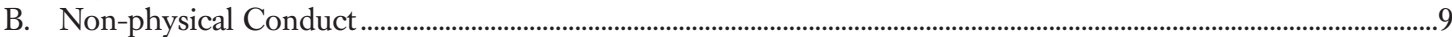

CHAPTER 4: State Criminal Laws: Defenses to Staff Sexual Misconduct .................................11

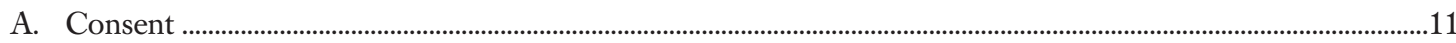

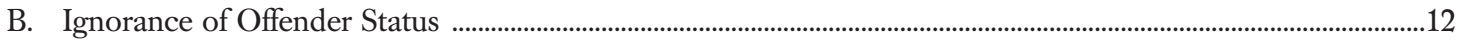

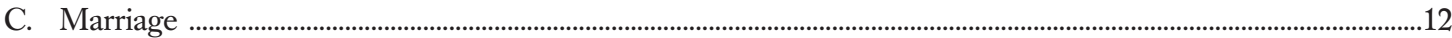

CHAPTER 5: State Criminal Laws: Criminal Penalties..................................................13

A. Sanctions for Offenders ...........................................................................................................................................................13

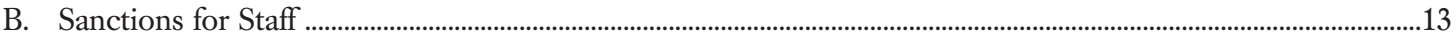

CHAPTER 6: Optimal Elements of Law: Criminalizing Staff Sexual Misconduct with Offenders ...........15

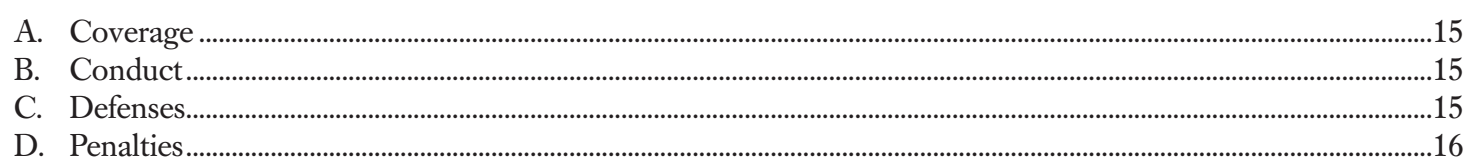

CHAPTER 7: Other Sanctions and Consequences...........................................................

A. Sex Offender Registration .......................................................................................................................................................................17

B. Duty to Report Sexual Abuse of Offenders ………………………………………………………………………………….....17

C. Mandatory Reporting: Juveniles and Vulnerable Persons .........................................................................................18

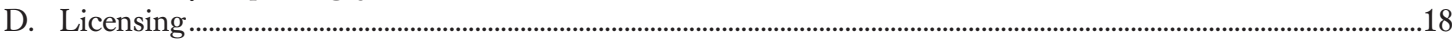

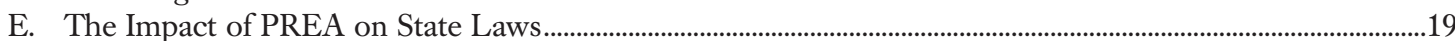

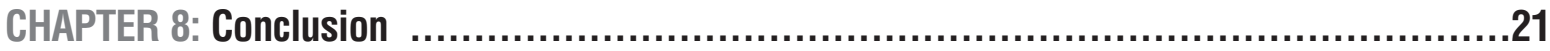

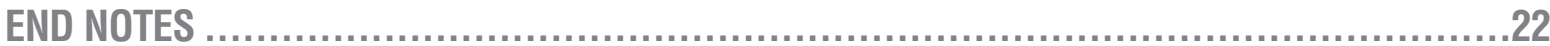

APPENDIX

A. 2009 Quick Reference Guide to the Fifty State Survey of Criminal Laws Prohibiting the Sexual Abuse of Individuals Under Correctional Supervision

B. Endnotes: 2009 Quick Reference Guide 


\section{An Introduction to Staff Sexual Misconduct: Definitions}

Finally, this publication concludes by reviewing the policy issues that stakeholders and policymakers should consider when evaluating a state criminal law on staff sexual misconduct, and provides recommendations for strengthening state laws to enhance their effectiveness.

\section{Understanding Staff Sexual Misconduct}

Sexual misconduct in correctional settings, like all forms of sexual abuse, is about asserting power. The imbalance of power between offenders in custody and those responsible for their care makes staff sexual misconduct not only inappropriate, but dangerous. Corrections staff and personnel, even volunteers, wield a high degree of power over offenders. They determine the amount of freedom an offender enjoys within a facility and can even influence an offender's access to the outside world through parole or work release. Offenders, in turn, may fear being denied freedoms if they fail to respond to staff advances.

Staff who engage in sexual misconduct with offenders often argue that the offender willingly participated in the sexual acts. Most correctional experts agree that there is an inherent power imbalance between staff and offenders. Consequently, it is difficult to determine whether an offender's "consent" was obtained through duress, fear or need. So, though an offender may "agree" to engage in sexual activity, the offender may not be consenting. The offender's status and the consequences of refusal influence his or her decision-making process.

It is useful to think about sexual behavior as behavior that occurs along a continuum-from forced conduct at
This publication provides examples of current state criminal laws on staff sexual misconduct and discusses the legal implications of these statutes. 
one end to consensual conduct at the other, with coerced and strategic sex between the two points. Sexual interactions are not static and can shift along the continuum depending on the circumstances between the individuals involved. The best correctional policies recognize that, regardless of where an offender or staff member sees his conduct along that continuum, civilized society does not tolerate these interactions in a custodial setting controlled by the state.

\section{Definitions of Staff Sexual Misconduct}

Over the years, both law and policy have created definitions of staff sexual misconduct. The first definitions of staff sexual misconduct appeared in correctional policies developed through litigation challenging sexual abuse of women in custody. ${ }^{6}$ These policies identified specific acts that constituted staff sexual misconduct including: sexual harassment, sexual intercourse, oral sex, sexual advances, requests for sexual favors, and other verbal or physical conduct of a sexual nature directed by a correctional employee against a prisoner. ${ }^{7}$ These policies also included invasions of female prisoners' privacy by male employees without a valid penological reason. ${ }^{8}$

In addition to these definitions forged in litigation, there are five other sources of definitions of staff sexual misconduct: (1) The Prison Rape Elimination Act (PREA); (2) the Bureau of Justice Statistics; (3) federal criminal law; (4) state and local correctional policy; and (5) state criminal law.

\section{The Prison Rape Elimination Act of 2003}

Congress passed the Prison Rape Elimination Act (PREA) in 2003. ' PREA's passage brought national attention to sexual violence in custodial settings and demonstrated Congress' concern about offender-onoffender sexual violence and staff-on-offender sexual violence. ${ }^{10}$ Several states are also in the process of passing or passed laws implementing PREA. ${ }^{11}$

While PREA does not create a legal definition for staff sexual misconduct, it defines "prison rape" as the rape of an offender in actual or constructive control of prison officials. ${ }^{12}$ PREA applies to all individuals in "prison, ${ }^{13}$ local jails, police lock-ups, parole, probation and juvenile facilities" and to "private organizations that contract with the government to run any facilities."14

\section{Bureau of Justice Statistics}

Under PREA, the Bureau of Justice Statistics (BJS) must collect data on the incidence and prevalence of staff-on-offender and offender-on-offender sexual violence in custodial settings. ${ }^{15}$ To carry out this task, PREA authorized BJS to consider "how prison rape should be defined for the purposes of its statistical review and analysis." ${ }^{16}$ With this mandate, BJS developed definitions of staff-on-offender and offender-onoffender sexual misconduct, drawing from training developed by the National Institute of Corrections, the Centers for Disease Control, and from meetings with interested persons. ${ }^{17}$ BJS defines staff sexual misconduct as:

"[a]ny behavior or act of a sexual nature, either consensual or non-consensual, directed toward an inmate by an employee, volunteer, contractor, official visitor, or agency representative. Such acts include:

- intentional touching of the genitalia, anus, groin, breast, inner thigh, or buttocks with the intent to abuse, arouse or gratify sexual desire; or

- completed, attempted, threatened, or requested sexual acts; or

- occurrences of indecent exposure, invasion of privacy or staff voyeurism for sexual gratification." ${ }^{, 18}$

According to BJS, staff sexual harassment is:

"[r]epeated verbal statements or comments of a sexual nature to an inmate by an employee, volunteer, contractor, official visitor, or agency representative. Such statements include demeaning references to gender or derogatory comments about body or clothing; or profane or obscene language or gestures." ${ }^{19}$

BJS used these definitions to determine the prevalence of sexual violence in correctional settings. Though these definitions are broader than state criminal laws prohibiting staff sexual misconduct with offenders, they have informed national data collection netting not just sexual acts themselves, but also inappropriate conduct of a sexual nature including abusive language and conduct. PREA and the BJS data collection underscore that staff sexual misconduct in federal, state, local and private correctional institutions is unacceptable, and 
that institutions entrusted with the care of offenders will be held accountable for staff sexual misconduct. ${ }^{20}$

\section{Federal Criminal Law}

At mid-year 2008, 201,142 prisoners were serving sentences in federal facilities in the United States ${ }^{21}-$ all of which prohibit sexual abuse of persons under correctional supervision. Federal criminal law prohibits sexual acts, sexual abuse, and sexual contact between staff and offenders. ${ }^{22}$ The federal law prohibits sexual abuse of a ward and provides:

"Whoever, in the special maritime and territorial jurisdiction of the United States or in a Federal prison, or in any prison, institution, or facility in which persons are held in custody by direction of or pursuant to a contract or agreement with the Attorney General, knowingly engages in a sexual act with another person who is - (1) in official detention; and (2) under the custodial, supervisory, or disciplinary authority of the person so engaging; or attempts to do so, shall be fined under this title, imprisoned not more than 15 years, or both."

A 2005 report issued by the Office of Inspector General (OIG) criticized the federal law ${ }^{23}$ criminalizing the sexual abuse of persons in custody and recommended several amendments. The OIG criticized the law's failure to cover individuals employed at contract facilities, particularly because the Bureau of Prisons (BOP) contracts routinely with private facilities to accommodate a 33 percent jump in the federal inmate population between 1999 and 2004. In its report, the OIG urged Congress to make staff in private facilities that contract with the federal government criminally liable for staff sexual misconduct with individuals under supervision. As a result of the report federal law was amended and now extends criminal liability to staff of federal prisons or "any prison, institution, or facility in which persons are held in custody by direction of or pursuant to a contract or agreement with the Attorney General." ${ }^{24}$

The OIG also recommended increasing the penalty for sexual abuse of an individual in custody from a misdemeanor to a felony. In response, Congress amended the federal criminal law on staff sexual misconduct in $2006^{25}$ to increase the penalty for sexual misconduct with individuals under federal custody from a misdemeanor penalty of one year to a five year felony. The federal penalties for staff sexual misconduct were increased again to fifteen years, with the passage of the Adam Walsh Act. ${ }^{26}$

\section{State and Local Correctional Agency Policy}

State and local corrections agency policy provides another source of definitions of staff sexual misconduct. ${ }^{27}$ Many institutions have policies specifically addressing staff sexual misconduct. In most cases, these state and local agency policies predated the enactment of PREA and are based upon state criminal laws on staff sexual misconduct. Policies vary from state to state, locality to locality, and even among individual facilities in each state. Despite this diversity, agency policies are an important source of definitions of staff sexual misconduct.

Generally, correctional agencies define prohibited conduct more broadly than state criminal laws. For example, many agency policies prohibit any contact - sexual or otherwise - with an offender or his family without a legitimate penological reason. Policies that are broader than state laws can be effective deterrents to staff sexual misconduct. While agency policies do not have the same legal effect as criminal laws, they put staff and offender on notice that engaging in sexual activity is prohibited and can lead to administrative and criminal sanctions for staff, and in some states, offenders as well. ${ }^{28}$ Additionally, institutions can tailor policies to their own experiences with staff sexual misconduct, often making these policies more nimble and targeted than state laws.

\section{State Criminal Law}

While federal criminal laws and state and local agency policies are important tools for addressing staff sexual misconduct, state criminal laws are perhaps the most important mechanisms for addressing sexual misconduct in correctional settings in the U.S. This is because the large majority of the nation's offenders are under the jurisdiction of state and local officials. While federal laws cover roughly 201,142 offenders under federal supervision, ${ }^{29}$ state law covers the other $7,312,498$ pris- 
oners (state and local) and probationers and parolees under custodial supervision. ${ }^{30}$ These state criminal laws create a baseline of liability for misconduct and provide important routes to other sanctions, including official misconduct ${ }^{31}$, loss of license ${ }^{32}$ and sex offender registration. ${ }^{33}$ State criminal laws are also flexible instruments that often reflect the political and social priorities of the state. In its 2005 report, the OIG reaffirmed the important role that state laws play in addressing staff sexual misconduct by comparing the federal law to existing state laws. ${ }^{34}$

In 1990, approximately 18 states, the District of Columbia and the federal government had criminal laws prohibiting the sexual abuse of individuals in custody. ${ }^{35}$ By 2006, each of the fifty states had enacted laws protecting offenders from sexual abuse by staff. ${ }^{36}$ While this progress is com- mendable, gaps still remain. States are constantly amending their staff sexual misconduct laws to cover a greater range of facilities, personnel, and situations, and implementing stronger penalties. ${ }^{37}$ The statutory language of these laws has a significant impact on their effectiveness in combating staff sexual misconduct.

In evaluating the effectiveness of these state laws, stakeholders should consider four questions:

(1) Which facilities and personnel are covered?

(2) What is prohibited conduct?

(3) What are defenses to criminal charges?

(4) What are the penalties for sexual misconduct?

The remainder of this publication will discuss these four questions in greater detail. 


\section{State Criminal Laws \\ Coverage of Agencies and Personnel}

n enacting staff sexual misconduct laws at the state level, each state must determine which personnel and which facilities, its law will cover. In each of these correctional settings, staff perform a range of functions including supervising offenders, managing the agency and/or facility, educating offenders, and providing food and medical care for offenders. Additionally, correctional agencies often use volunteers, contractors, and other government agencies and workers to provide services to offenders. Staff sexual misconduct occurs in all types of facilities that hold, incarcerate, and supervise individuals in custody. Therefore, determining which institutions, settings, and employees will be covered is a critical step in evaluating the effectiveness of state staff sexual misconduct laws. The most comprehensive laws will cover all individuals who interact with offenders in any capacity in any facility.

\section{Institutional Facilities and Personnel}

The growth in the number of people under custodial supervision in the United States, and the growth in corrections as a whole, has meant that arrangements for offender supervision have also grown. In addition to prisons, jails, police lockups and juvenile detention facilities, offenders may be supervised in less restrictive settings such as halfway houses, day reporting, electronic monitoring, treatment programs, contract facilities, and work programs-both state and privately run.

Some state laws only cover secure confinement facilities and their personnel. ${ }^{38}$ Some state laws are even more limited in scope and apply only to conduct that occurs inside a correctional facility.
For example, under New Mexico law, criminal sexual penetration in the second degree, is criminal sexual penetration perpetrated "on an inmate confined in $a$ correctional facility or jail when the perpetrator is in a position of authority over the inmate." ${ }^{39}$

Laws that specify that misconduct is illegal only when it occurs inside an institution provide no protection when the offense occurs outside facility walls, even when an offender is still in state custody. Thus, conduct that occurs while an offender is in transit, hospitalized outside the institution, or on work-release, for example, might not be covered by these statutes. ${ }^{40}$ These gaps in the law permit staff to engage in staff sexual misconduct without fear of punishment as long as the conduct occurs outside of a penal institution. Such gaps are short-sighted, because these interactions pose as great a threat to the safety and security of correctional environments and offenders as those occurring within institution walls.

\section{Community Corrections Agencies and Personnel}

State arrangements for community corrections vary throughout the country. These include: (1) unified systems like those in Florida, Kentucky and Rhode Island $^{41}$ where community corrections is part of the Department of Corrections; (2) systems where portions of community corrections-usually probation-fall under local court jurisdictions, as in Indiana, Kansas and West Virginia; ${ }^{42}$ and (3) systems where community corrections is a separate independent agency as in Arkansas, South Carolina and Tennessee. ${ }^{43}$ 
A gap in many state laws is the failure to include sexual abuse of offenders in community corrections settings. This coverage is particularly important because a majority of offenders are supervised in the community through electronic monitoring, home detention, halfway homes, treatment centers, probation, parole, the courts, other government agencies (such as pretrial services) and private non-governmental entities. For the most part, state laws prohibiting the sexual abuse of persons in custody cover prisons and jails and their staff, but often do not apply to community settings or their staff. This gap provides little protection from staff in community settings who maintain inappropriate or sexual relationships with offenders under their care.

This failure to include community corrections is not accidental. Many states do not believe that sexual abuse occurs in the community or that this behavior is as serious or damaging as abuse that occurs in confinement. For example, Nevada law provides that sexual contact with an offender is only unlawful if an offender is under lawful custody or confinement other than in the custody of the Division of Parole and Probation or residential confinement. ${ }^{44}$

Most people understand that staff in community corrections settings, like staff in prisons and jails, wield a great degree of power over offenders. Offenders fear being returned to prison or jail if they do not cooperate with community corrections staff requests, and often see "cooperating" as their only alternative. This inherent power imbalance can contribute to staff sexual misconduct. ${ }^{45}$

While 43 states and the District of Columbia specifically prohibit sex between probation and parole staff and offenders, many limit coverage to persons with "supervisory or disciplinary authority" over the offender. ${ }^{46}$ This is particularly problematic for community agencies because while a community staff member may not directly supervise an offender or youth, s/he still can influence the offender's status. For example, a non-supervisory staff member may retaliate against an offender for refusing her advances, by placing negative reports in the offender's file, or by influencing that offender's relationship with his direct supervisor. Often community corrections staff share responsibilities for keeping track of offenders, even those not on their caseloads, e.g. drug screens or periodic reporting. Such reports can result in revocation of the offender's community status and incarceration. Facing the possibility of losing their parole or probation status, an offender may feel coerced into engaging in sexual relations with a community corrections officer.

In trying to address this problem, Wisconsin has recognized that criminal liability should extend beyond direct supervision. Wisconsin law holds probation, parole or extended supervision agents criminally liable for engaging in sexual intercourse or sexual contact with an individual whom they directly supervise or supervise through a subordinate, but also applies to any agent who influences or attempts to influence another probation, parole or supervision agent. ${ }^{47}$

Other states, rather than criminalizing acts based upon the location of the misconduct, criminalize conduct based on the actor's status as an employee of an agency or institution and the victim's status as an inmate, offender or youth in custody. Thus, these laws ensure that staff sexual misconduct is prohibited regardless of an offender's location in the system-be it arrest, lockup, jail, prison or community supervision. For example, Georgia law provides that an actor is guilty of sexual assault if the sexual contact is committed against a person who is in custody of law. ${ }^{48}$ Generally, states define custody of law as arrest, pretrial incarceration, incarceration in a prison or jail, parole or mandatory supervised release, electronic home detention, probation and/or parole. ${ }^{49}$

Given the variety of state arrangements for community corrections, general state statutes that prohibit sexual conduct between offenders and correctional staff must include specific language that brings community corrections agencies under the law. Statutes that provide broad and explicit coverage for community corrections settings, such as those in Kansas and Maine, assure accountability for community corrections staff who abuse their position of trust and power by sexually abusing persons under supervision. ${ }^{50}$

\section{State Juvenile Justice Agencies and Personnel}

Juvenile justice agencies represent another setting that many states neglect to include in staff sexual miscon- 
duct laws. Paying increased attention to child sexual abuse, ${ }^{51}$ Congress recently passed legislation aimed at establishing a national sex offender registry. ${ }^{52}$ Additionally, the allegations of system-wide sexual abuse of youth in custody in several states-Texas, Washington, Ohio and Indiana ${ }^{53}$-have pushed state legislators, advocates and corrections administrators to bring juvenile justice agencies within the scope of staff sexual misconduct laws. Adding specific language concerning juveniles is crucial, particularly given that most state juvenile justice agencies are not part of, nor under the control of, state departments of corrections which most state criminal laws cover.

Staff sexual misconduct within juvenile justice agencies is a serious and well-documented problem. ${ }^{54}$ In 2004, BJS found that juvenile agencies reported staff sexual misconduct rates nearly three times higher than those of adult facilities. ${ }^{55}$ In 2008 BJS released a report analyzing sexual violence in juvenile facilities in 2005 and $2006 .{ }^{56} \mathrm{In}$ that report, BJS found that $32 \%$ of all incidents reported by correctional authorities involved staff sexual misconduct and $11 \%$ involved staff sexual harassment of youth ${ }^{57}$ One-third of those incidents occurred outside juvenile facilities in community settings. ${ }^{58}$

Currently, 43 states and the District of Columbia have staff sexual misconduct laws that cover employees of juvenile justice agencies. ${ }^{59}$ These states use several approaches. For example, Kansas law applies to all types of settings in the state, covering juvenile detention facilities, sanction houses, juvenile correctional facilities, juvenile justice authorities, juvenile community supervision, and those who contract with these institutions. ${ }^{60}$ In contrast, eight states exclude juvenile justice agencies from coverage. ${ }^{61}$ For example, Rhode Island law prohibiting staff sexual misconduct covers all employees of the Department of Corrections (DOC), ${ }^{62}$ but the law does not apply to juvenile justice agencies because the Department of Juvenile Justice (DJJ) and the DOC are separate agencies.

Often states believe that existing statutory rape statutes adequately address staff sexual abuse of youth in custody. However, often these laws only provide protection for youth under the age of consent, generally 16 years old in most states; leaving older youth at risk. ${ }^{63}$ Additionally, penalties for statutory rape tend to be less than those in staff sexual misconduct laws. ${ }^{64}$

States should also be aware of who governs and maintains juvenile facilities when creating law. Private corporations run an increasing number of facilities for juveniles. The 2004 BJS study revealed that private juvenile facilities, although fewer and smaller in size, have rates of staff sexual abuse only slightly lower than those of state and federal juvenile institutions. ${ }^{65}$ States should consider the role that private corrections play in their juvenile facilities, and ensure that staff sexual misconduct laws extend coverage to private entities as well.

\section{Private Facilities and Personnel}

With the growth of incarcerated populations and smaller correctional budgets, many states contract with private correctional facilities operated by companies like Wackenhut, Corrections Corporation of America, Cornell Companies and Youth Services International to care for offenders. ${ }^{66}$ These states contract with private facilities sometimes in other states for housing, supervision, home monitoring or work release programs. ${ }^{67}$ This means a large number of offenders are under the jurisdiction of private entities, and, barring specific laws, offenders may go unprotected from staff sexual misconduct.

Currently 36 states and the District of Columbia have sexual misconduct laws that include these private contract facilities and their employees. ${ }^{68}$ There are a number of legislative approaches that states have used to cover private facilities. For example, Ohio law provides that "no person shall engage in sexual conduct with another person if the person is housed in a detention facility." The law goes on to describe a detention facility as any public or private place used for the confinement of a person charged with or convicted of a crime. ${ }^{69}$ North Dakota, covers private facilities under language that prohibits sexual abuse that occurs at "other institutions." ${ }^{\text {"0 }}$ Those other institutions include private contract facilities.

In the 2006 BJS study of Sexual Abuse Reported by Correctional Authorities, over half of all private agencies reported having at least one incident of sexual abuse in their facilities. ${ }^{71}$ While this translates to less 
than one percent of all reported allegations, it is nonetheless troubling considering the smaller number of offenders housed in private facilities and the different reporting structures that can often exist in them.

The failure to cover private facilities under state criminal laws prohibiting the abuse of persons under correctional supervision leaves both states and private facilities open to civil liability. ${ }^{72}$ Private facilities and their staff function as any other prison, jail, community or juvenile facility taking on important state functions, thus coverage in these settings is just as important as in any state-run agency.

\section{Other Staff in Correctional Settings: Contractors and Volunteers}

A correctional agency's staff is comprised of more than correctional officers. Volunteers and contractors such as food service personnel, clergy, teachers, maintenance workers, and medical and mental health staff all have regular contact with offenders in correctional settings.

When state law covers only employees of the department-meaning correctional officers and administrators-it fails to acknowledge the harm that other staff can cause. ${ }^{73}$ States often contract with other entities for medical care, education, food service and other functions. In a host of reported cases, individuals other than correctional officers or institution administrators, including psychologists, ${ }^{74}$ maintenance workers,${ }^{75}$ medical personnel $^{76}$ and drug and alcohol counselors ${ }^{77}$ abused offenders. In drafting law and policy, states should ensure that laws include provisions prohibiting abuse by any and all staff who come into contact with offenders.

\section{Contractors}

Currently, 46 states and the District of Columbia include contractors in their staff sexual misconduct laws. ${ }^{78}$ Many state laws criminalizing staff sexual misconduct cover these additional employees by including a specific list of employees who can be held liable for staff sexual misconduct. Lists can include but are not limited to: employees of medical and mental health institutions, ${ }^{79}$ teachers,${ }^{80}$ counselors, ${ }^{81}$ and vendors. ${ }^{82}$ For example, Texas law covers "[a]n official of a correctional facility, an employee of a correctional facility, a person other than an employee who works for compensation at a correctional facility, a volunteer at a correc- tional facility, or a peace officer." ${ }^{83}$ While California's law is less specific than Texas, it does include an employee or officer of a public detention facility, "an employee officer or agents of a private person or entity and a volunteer of a public or private entity." ${ }^{\prime 4}$

\section{Volunteers}

Many states utilize volunteers in their correctional facilities. While reports confirm that volunteers also engage in sexual abuse of individuals in custody, they are often excluded from staff sexual misconduct laws. ${ }^{85}$ However, only about half of states include volunteers in their staff sexual misconduct laws. Currently only 27 states and the District of Columbia prohibit volunteers from abusing offenders. ${ }^{86}$ Some states list volunteers explicitly as a class of personnel who will be held criminally liable for engaging in sexual misconduct with an offender. For example, Iowa, Minnesota and South Carolina, all cover volunteers in their staff sexual misconduct laws. ${ }^{87}$ Comprehensive laws provide states with tools to address misconduct perpetrated by all personnel within an offender and states who utilize volunteers should consider specifically including them in laws prohibiting sexual abuse in custody.

\section{Staff with Supervisory and Disciplinary Authority}

Another class of staff penalized for staff sexual misconduct is individuals with supervisory or disciplinary authority over offenders. Most commonly, correctional staff members responsible for supervision and discipline of offenders include correctional officers, wardens, correctional administrators, probation/parole officers and youth workers. ${ }^{88}$ Requiring that a staff perpetrator supervise or discipline an offender leaves many correctional staff members outside coverage of the staff sexual misconduct law, and particularly nonsecurity staff. These include volunteers and contract staff such as clergy, teachers, medical staff or food service workers who do not discipline, supervise or exercise custody over offenders. However, many employees without direct supervisory or disciplinary control over offenders nevertheless have the opportunity to engage in sexual misconduct. Staff sexual misconduct laws should include all employees of agencies who interact with offenders, including contract staff and other personnel as well as paid or unpaid staff. 


\section{State Criminal Laws: Prohibited Conduct}

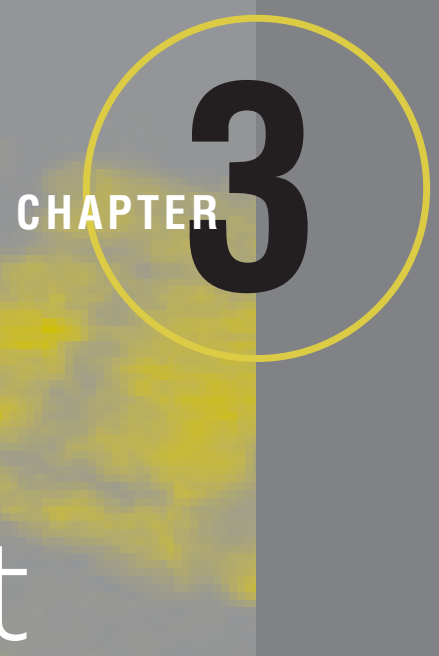

riminal laws prohibiting staff sexual misconduct with offenders differ in the types of conduct they cover. Laws in most states cover all or a combination of the following: intercourse or penetration of the vagina, mouth, or anus by a penis, finger, or any object, touching or fondling over the clothing or under the clothing, and masturbation. ${ }^{89}$ Generally, staff sexual misconduct laws cover only the most serious sexual conduct. They may not cover taking photographs, voyeurism, forcing someone to masturbate or forcing someone to have sex with someone else. Staff sexual misconduct laws also generally do not prohibit touching or fondling, masturbation, or non-physical behaviors like correspondence or conversations that are sexual in nature, even though they are often precursors to more serious sexual acts that include penetration.

\section{Physical Conduct}

The specificity with which each law describes illegal sexual acts varies by state. Many state laws use words such as "intercourse" and "contact" but do not specifically define what those terms mean. When staff sexual misconduct laws do not define those words explicitly, it becomes more difficult to determine what kind of sexual behavior is actually prohibited. Thus, many laws leave important questions unanswered. For example, is the emission of semen required to complete the act? Is slight penetration considered intercourse? Can the sexual contact be with any part of the body? Does penetration include penetration with objects?

For example, Mississippi law provides that it is against the law to "engage in any sexual penetration or have carnal knowledge of any offender." ${ }^{90}$ While this law covers penetration, it does not include acts such as sexual fondling or contact for sexual gratification. In contrast, Kentucky law prohibits "any touching of the sexual or other intimate parts of a person done for the purpose of gratifying sexual desire of either party." ${ }^{\text {"19 }}$ States should keep in mind that there are many kinds of sexual behavior-including fondling and touching as well as self-stimulation. Staff who engage in these acts with offenders are still committing staff sexual misconduct.

In sum, the most inclusive laws acknowledge that an act of intercourse or penetration, as well as touching, fondling, inappropriate viewing, photography, exposing oneself, and masturbation by staff all constitute staff sexual misconduct, and should be prohibited by statute.

\section{Non-Physical Conduct}

Currently, state staff sexual misconduct laws do not prohibit or criminalize non-physical sexual conduct such as conversations or letters of a sexual nature between adults. Though non-physical sexual activity may not be prohibited by state law, states and agencies should endeavor to prohibit this type of behavior through agency policies. While non-physical, the sexual nature of such conduct has the potential to escalate into physical sexual misconduct. In order to combat staff sexual misconduct, agency policy should prohibit all acts that are sexual in nature between staff and offenders.

In Riley v. Olk-Long, what began as an officer's inappropriate sexual comments to an offender soon escalated into physical sexual misconduct. In this case, the officer 
asked an inmate if she was having a sexual relationship with her roommate at the facility, and, if so, if he could watch the two of them engaging in sexual activity. After the facility assigned the inmate a new roommate, "a known bisexual," the officer observed the two in their room together and asked "when's the show?" These non-physical sexual advances by the officer eventually escalated into the rape of the inmate by the correctional officer.

Like laws in many states, Iowa law does not prohibit non-physical conduct such as verbal harassment or voyeurism. This case, however, illustrates the importance of prohibiting non-physical sexual conduct in agency policy. As already discussed, agency policy can be an effective way to combat staff sexual misconduct and put correctional employees on notice that any sexual behavior can result in administrative discipline. Ensuring that agency policy addresses non-physical sexual conduct can help prevent physical sexual con- duct by staff against offenders, in this way, agency policies can work hand-in-hand with state staff sexual misconduct laws.

Although often outside the scope of state criminal staff sexual misconduct laws, when non-physical staff sexual misconduct involves juveniles other state and federal laws do cover the conduct. The Adam Walsh Child Protection and Safety Act of $2006^{93}$ strengthens state and prior federal laws that protect children from sexual predators by prohibiting voyeurism as well as possession, production or distribution of child pornography. ${ }^{94}$ The Act also sets forth specific definitions and instructions regarding child pornography and sex offender registration for adults possessing and/or distributing pornography. ${ }^{95}$ Additionally, state mandatory reporting and abuse statutes cover a broad range of conduct that may be non-physical in nature but is still considered dangerous to minors. This conduct includes photography. ${ }^{96}$ 


\section{State Criminal Laws: Defenses to Staff Sexual Misconduct}

\section{Consent}

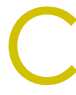

onsent is the most often-used defense in staff sexual misconduct cases. Laws in 23 states and the District of Columbia specifically prohibit consent as a defense to staff sexual misconduct charges. ${ }^{97}$ For example, Alabama's staff sexual misconduct law provides that "consent of the person in custody of the Department of Corrections, the Department of Youth Services, a sheriff, a county, or a municipality, or a person who is on probation or parole shall not be a defense to prosecution under the law." ${ }^{\prime 8}$ Some state criminal laws are not as clear on the issue of consent. Alaska law, for example, provides that consent is not a defense only when staff engages in sexual penetration with an offender s/he "knows is mentally incapable," such as the mentally ill, the mentally retarded, or those with other mental disabilities.9

Not all states agree on this matter, however. While 25 states do not address consent explicitly, there are two states-Delaware and Nevada-that consider offenders capable of consenting to sexual relations with correctional employees. ${ }^{100}$ These states punish both the offender and the responsible staff member for engaging in sex thereby making consent an acceptable defense to staff sexual misconduct. These laws, either intentionally or unintentionally, create a climate where staff can threaten to report that the sex between the staff member and offender was consensual, thus exposing the offender to criminal prosecution. Under these circumstances, offenders are even more unlikely to report sexual abuse or contact for fear of being prosecuted.
It is often difficult for correctional staff, investigators and prosecutors to distinguish coercion from consensual sexual activity, especially when physical signs of force are absent. ${ }^{101}$ Most correctional experts agree that there is an inherent power imbalance between staff and offenders. Therefore, though an offender may agree to engage in sexual activity, the offender may not be consenting. The offender's status and the consequences of refusal influence his or her decision-making ability. An offender's "consent" could have been obtained under duress or through fear or need.

In response, many legislatures have enacted laws that eliminate consent as a defense in these cases, much like in the case of underage youth and people with disabilities. Many courts have ruled that the inherent power disparity between offenders and staff members renders true consent impossible in the correctional context. ${ }^{102}$ At the Winn Correctional Center, in Louisiana, for example, a prison correctional officer coerced a male inmate into oral sex by threatening to confine him with dangerous inmates. ${ }^{103}$ The correctional officer was sentenced to five years in prison for the offense. ${ }^{104}$

The prevailing best practice view is that all sex between staff and offenders, regardless of the gender of staff or offender, is non-consensual. Well developed laws recognize that offenders may have complex motivations for engaging in sexual activity with staff members, including safety and self-protection, ${ }^{105}$ and therefore that consent is never present.

Moreover, although offenders might admit that they entered into a sexual relationship "voluntarily," states 
can still choose to make this conduct illegal as a matter of law-much like statutory rape law. ${ }^{106}$ States that fail to explicitly stipulate that consent is not a defense to sexual misconduct make successful prosecution and conviction of staff in these cases more difficult. From a management and public policy perspective, overlooking "consensual" sex between staff and offenders severely impedes legitimate correctional goals of agency security, offender management, offender rehabilitation and staff morale.

\section{Ignorance of Offender Status}

In ten states, staff members who can prove they were unaware of an offender's correctional status can use that ignorance as a defense to criminal prosecution for staff sexual misconduct. ${ }^{107}$ Since knowledge that the offender is under supervision of a correctional agency generally will result in a guilty verdict, courts can dismiss this defense easily if the conduct occurs inside of a correctional institution. Thus, staff uses this defense most often when the misconduct takes place while an offender is on probation, parole or other post-release supervision. Staff have successfully claimed that they were unaware of the offender's status in these situations.

For example, Virginia's staff sexual misconduct law finds a person guilty of "carnal knowledge of an offender-victim" if s/he "know [s] that the inmate, probationer, parolee, detainee, or pretrial or post-trial offendervictim is under the jurisdiction of the state or local correctional facility, regional jail, the Department of Corrections, the Department of Juvenile Justice, a secure facility or detention home, a local court services unit, community based probation services agency, or a pretrial services agency."108

This is another area where institutional policy can close the gaps in state law. Most agencies have antifraternization policies which make clear that staff may not engage in sexual or other interactions with offenders or their families. These policies are an effective way to stress to employees that intimate relationships with offenders will not be tolerated, before such incidents are serious enough to trigger criminal prosecution. ${ }^{109}$
Incorporating a duty-to-report requirement within agency policy is even more effective. These policies mandate that when a correctional employee learns that someone with whom she is socializing or doing business is an offender, she must immediately inform the institution about that interaction. This provides both the institution and the employee an opportunity to mitigate any harm that relationship may pose to the employee's job performance or to the institution's safety, security and reputation. Law and policy can thus work together to ensure that employees do not subvert the system by claiming that they were unaware of an offender's status.

\section{Marriage}

In 19 states and the District of Columbia, marriage between a staff member and an offender is considered a defense to laws criminalizing sexual conduct. ${ }^{110}$ In Alaska, it is a defense to staff sexual misconduct if the offender is "married to the person and neither party has filed with the court for a separation, divorce or dissolution of the marriage." ${ }^{111}$ New Jersey is the only state that specifies that marriage is not a defense to staff sexual misconduct with an offender. ${ }^{112}$ The remaining states do not address whether employees can use marriage to an offender as a defense.

Like duty-to-report requirements, agency policies on marriage can also augment state law and help prevent staff sexual misconduct. ${ }^{113}$ Institutional policies that require staff to report social interactions with offenders would certainly apply to marriage. Prior to the offender's incarceration, such policy allows the institution to monitor the relationship and make necessary adjustments to housing arrangements or to staff assignments for supervising the offender. When the marriage occurs either during or post incarceration, states have policies and legal decisions have routinely upheld the ability of agencies to discipline or terminate staff. Prosecution, however, is much less likely because of the explicitly consensual nature of marriage and state immunity statutes which prevent spouses from testifying against each other. 


\section{State Criminal Laws: Criminal Penalties}

enalties for engaging in staff sexual misconduct vary among the states. Criminal penalties have increased as lawmakers and correctional administrators have realized the threat that staff sexual misconduct poses to the safety of correctional institutions and the harm such violations cause to offenders. However, ensuring that penalties reflect the seriousness of these crimes has been a lengthy process requiring the support of legislators, prosecutors and the correctional community across the country. Some states still lag behind, continuing to penalize offenders themselves for sexual conduct with staff, or impose only misdemeanor penalties on staff guilty of staff sexual misconduct.

\section{Sanctions for Offenders}

Delaware and Nevada impose penalties on offendervictims of staff sexual misconduct where they deem the conduct is consensual. In Delaware, a "person is guilty of sexual relations in a detention facility when being a person in custody the person engages in sexual intercourse or deviate sexual intercourse." ${ }^{114}$ In Delaware this is a Class $G$ felony punishable by up to two years of incarceration. In Nevada, "a prisoner in lawful custody or confinement" and "who voluntarily engages in sexual conduct with another person" is guilty of a category D felony punishable by one to four years in prison and a fine of not more than $\$ 5,000 .{ }^{115}$

States that choose to penalize offenders for staff sexual misconduct have rejected the view that offenders' decision-making is clouded by the power imbalance between offenders and staff. Instead, they implicitly find that offenders are capable of consenting to sexual relationships with staff.

While these penalties may send a message to offenders, they also have a chilling effect on reporting and prosecution of staff sexual misconduct. ${ }^{116}$ Offender cite fear of retaliation or punishment as the number one reason for failing to report staff sexual misconduct. Laws that punish offenders create an environment in which they fear prosecution, either because they voluntarily engaged in the behavior or fear they will be accused of doing so. In turn, these policies also increase the likelihood that staff will escape punishment. As a result, few states criminally sanction offenders in situations of staff sexual misconduct even when the law permits it. Most states recognize that staff members should be held to a higher standard of conduct, regardless of an offender's behavior, and that offenders should be encouraged to report sexual misconduct. Nevertheless, these policies help to create a climate that inhibits reporting and fosters a sense of impunity among staff.

\section{Sanctions for Staff}

Until recently, the penalty in many states for staff engaging in staff sexual misconduct with offenders was a misdemeanor. The trend is now moving toward more stringent penalties for offending staff. ${ }^{117}$ Today, only three states--Iowa, Kentucky, and Maryland-retain misdemeanor penalties for staff sexual misconduct $^{118}$ where penalties range from imprisonment not exceeding one year to imprisonment up three years.

In Iowa, a person found guilty of sexual misconduct can be sentenced to an aggravated misdemeanor 
charge carrying a prison term not to exceed two years and a fine of at least $\$ 625$ but not to exceed $\$ 6,2500^{1{ }^{11}}$ In Kentucky, staff sexual misconduct is a Class A misdemeanor and carries an imprisonment term not to exceed twelve months. ${ }^{120}$ In Maryland, guilty staff is subject to imprisonment not exceeding three years or a fine not exceeding $\$ 3000$ or both. ${ }^{121}$

Having laws that only carry misdemeanor sanctions can leave states vulnerable. Prior to 2005, the federal law prohibiting sexual abuse of individuals under custodial supervision was a misdemeanor. When conducting research for a report on sexual abuse in federal custodial settings, the Office of Inspector General (OIG) found that the misdemeanor penalty presented several problems. ${ }^{122}$ First, the sanction was one year and only garnered more severe penalties if the staff used force or threats. ${ }^{123}$ Because of the power and control staff exercise, they rarely needed to use force or threats to gain the compliance of offenders. Second, prosecutors were reluctant to prosecute staff of sex abuse cases, and even less reluctant because of the low penalty. These low penalties signaled to prosecutors, the public and offenders the lack of importance of these offenses. ${ }^{124}$ Additionally, with the common practice of plea bargaining, it gave prosecutors very little room to negotiate with staff and their lawyers.
Thirty-eight states and the District of Columbia currently provide felony sanctions for staff sexual misconduct. ${ }^{125}$ In most states, the penalty includes both a fine and a prison term. In general, fines range from fivehundred to $\$ 50,000,{ }^{126}$ and prison terms may range from one year to life in prison. ${ }^{127}$

In nine states-Alaska, California, Colorado, Connecticut, New York, Oregon, Utah, Virginia and Washington-the penalty for staff sexual misconduct varies, based on factors such as the severity of the crime and the age of the victim. ${ }^{128}$ For example, in Connecticut, the charges and penalties can vary, depending on the age of the victim. If the victim is over 16 years old, the crime is a Class $\mathrm{C}$ felony carrying a penalty of one to ten years in prison, but if the victim is under 16 the crime is a Class B felony carrying a maximum prison term of 20 years. ${ }^{129}$

As illustrated, states have very different schemes for penalizing staff sexual misconduct with offenders. What is clear is that in order to diminish these behaviors swift investigation, prosecution and penalties carrying felony convictions should be the rule. 


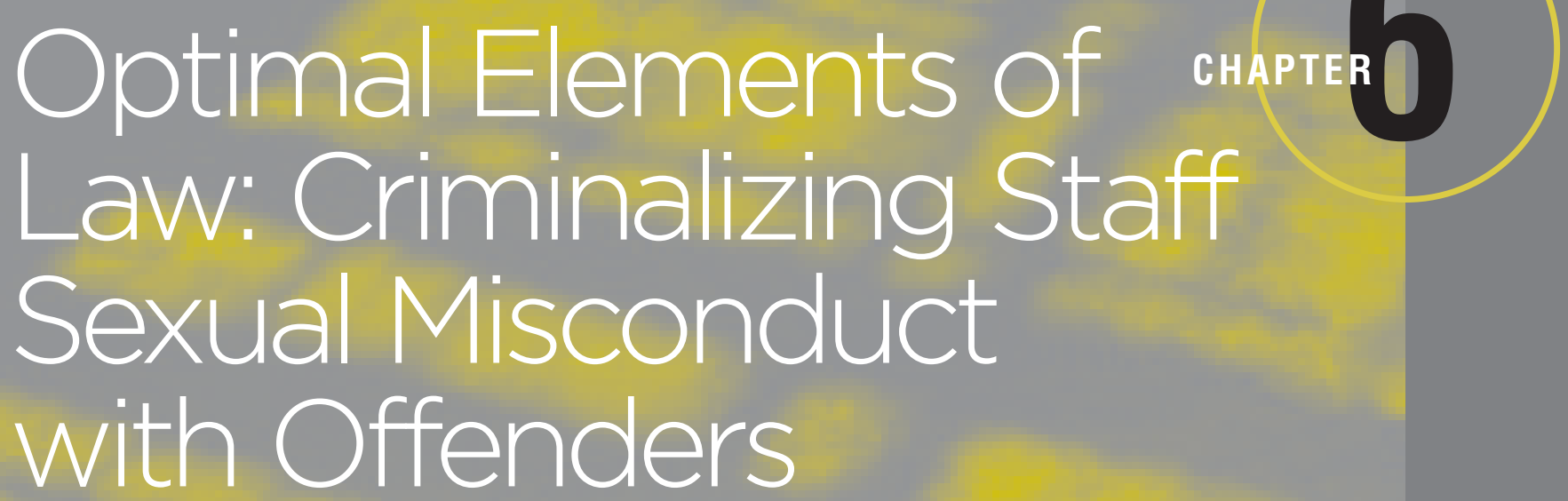

B

fore enacting or modifying criminal staff sexual misconduct laws, states will first need to consider the political climate. Support from legislators and other stakeholders is critical to efforts to improve state staff sexual misconduct laws. The enactment of PREA and its reporting provisions may provide legislators an important incentive to reexamine and improve existing state laws.

There are several resources that can aid states in this endeavor. First, agencies should examine other state laws. Appended to this publication (Appendix A) is the 2009 Quick Reference Guide to the Fifty-State Survey of State Criminal Lawos Prohibiting the Sexual Abuse of Individuals in Custody. Additionally, you can find an electronic version of both the Quick Reference Guide and the full Fifty-State Survey of State Criminal Lazes Prohibiting the Sexual Abuse of Individuals in Custody with the most recent updates at www.wcl.american.edu/nic/responses.

As detailed in this publication, any analysis of state laws prohibiting sexual abuse of individuals in custody should consider the following elements: (1) coverage; (2) prohibited conduct; (3) defenses; and (4) penalties. A careful review of how state law addresses-or fails to address-these four elements will reveal areas where laws can be amended or improved.

\section{Coverage: Cover all state agencies, facilities and potential personnel}

A state should consider which state agencies, facilities and personnel it wants to include in the law. The most inclusive laws cover all actors in the criminal justice system by listing explicitly who can be held criminally liable. Such actors include staff in community corrections, private facilities, prisons, jails, other state agencies supervising offenders and juvenile institutions. Laws may also explicitly cover officers, administrators, contractors, food service employees, maintenance workers, teachers, health care employees, clergy, and volunteers. In other words, the most inclusive laws will cover any individual who may have direct or indirect contact with offenders in any correctional setting.

\section{Conduct: Cover sexual penetration/intercourse and inappropriate sexual contact}

The term "staff sexual misconduct" encompasses many activities-some of which may seem unusual to the average person. Including a wider spectrum of sexual behavior enhances opportunities to prosecute staff who engage in misconduct with offenders. No law can cover every sexual situation that may arise, or can criminalize conduct that may be sexual in nature but is not assaultive. Since internal policies can reach further than criminal law and are easier to create, institutions should augment their state laws with strong internal policies that include behaviors that criminal law does not cover. These behaviors include over-familiarity, harassment, oral and written communications, photography and invasion of privacy.

\section{Defenses}

\section{Consent should not be a defense}

Consent, presently not covered by more than half of states' laws, is a controversial legal issue. However, as a 
legal matter, the power differential between an offender and staff member negates consent. If staff members know that offenders can never "consent" to sexual activity, they will also know that offenders' consent will never negate their responsibility or prosecution. Laws that specifically state consent is not a defense can help prevent staff from engaging in sexual activity with offenders.

\section{Marriage and ignorance of offender's status can be monitored through institutional policy}

Institutional policies are an effective way to address violators' defenses of marriage or ignorance of an offender's status. Policy should include prohibitions against inappropriate relationships with offenders and their families, and should sanction those who engage in these relationships. Moreover, staff should be informed of all policies during training and prior to beginning work. To strengthen the effectiveness of internal policy, a duty-to-report requirement should be included. Such a reporting requirement allows correctional administrators and staff the opportunity to handle staff-offender relationships before the conduct negatively affects agency safety and security.

\section{Penalties: State law should treat staff sexual misconduct as a serious criminal offense}

When considering the penalties and sanctions for a staff sexual misconduct conviction, lawmakers should consider the following: (1) which penalty (misde- meanor or felony) is more likely to result in prosecution, and what is the appropriate penalty for the offense; (2) if other collateral sanctions exist, such as loss of employment, loss of license, malfeasance in office or obstruction of justice; and (3) if offenders will be sanctioned for engaging in the conduct.

In both the 2005 and 2009 OIG Reports, in testimony to the National Prison Rape Elimination Commission and in research developed by the NIC/ WCL Project on Addressing Prison Rape, prosecutors are more likely to take on staff sexual misconduct cases when the crime yields a serious penalty. ${ }^{130}$ Since many state prosecutors are understaffed and poorly funded, they will often forego prosecuting misdemeanor crimes. ${ }^{131}$ Classifying staff sexual misconduct as a felony sends a message to prosecutors that corrections and legislators consider the crime a serious sex offense. Prosecutors, in turn, will come to view these cases as seriously as sex offenses that occur outside the correctional system.

State law should also add provisions to ensure that collateral sanctions will be enforced. Often internal institutional policy will address sanctions such as loss of license and/or employment. However, including these sanctions in existing laws will also provide additional tools for prosecutors. 


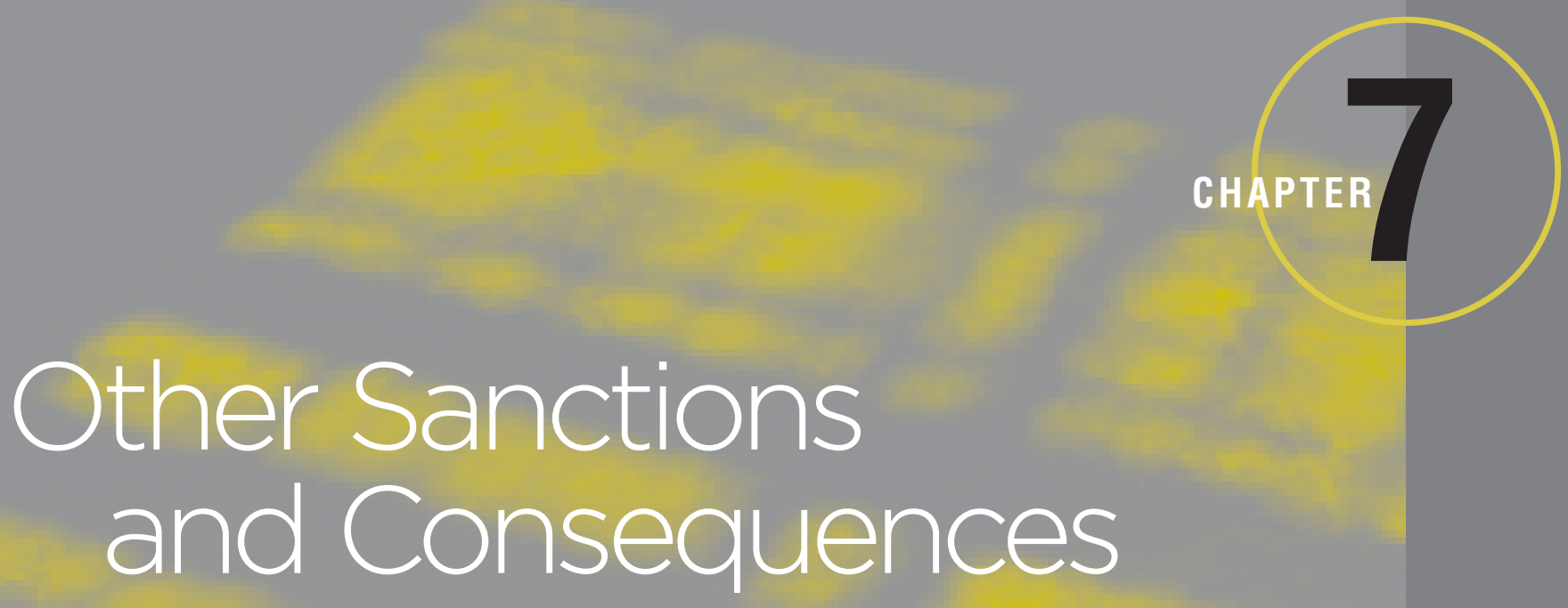

his publication reviews only a narrow category of sexual assault law that explicitly addresses sexual abuse of persons in custody. However, there are other criminal laws which allow prosecution of staff sexual misconduct such as rape or sexual assault, sodomy, official misconduct, mandatory reporting, reckless endangerment, mistreating a person in an institution, obstruction of justice and statutory rape..$^{132}$

In addition to the criminal penalties discussed above, convicted staff can face additional consequences for staff sexual misconduct convictions, including sex offender registration and/or loss of a professional license. Though these consequences are not considered punitive like fines and imprisonment, they can burden individuals' life and thereby deter staff sexual misconduct in some cases.

A few of these tools are reviewed in brief below. However, more in-depth analysis of issues surrounding sex offender registration, mandatory reporting and vulnerable persons will be discussed in greater detail in forthcoming publications.

\section{Sex-Offender Registration}

Criminal laws prohibiting staff sexual misconduct, like other sexual assault statutes, can trigger sex offender registration. Currently, in 32 states, an individual convicted of staff sexual misconduct can be compelled to register as a sex offender in addition to incarceration. ${ }^{133}$

Though sex offender registration is not considered a criminal penalty, the registration requirements do create hardships that infringe on an individual's daily

life. ${ }^{134}$ Those hardships include restrictions on where one may reside, work and community notification, where an offender's personal information is posted on a public website and made available to the public and/or law enforcement.

While there is significant and legitimate criticism about the overbreadth of sex offender registration requirements, it is one of the few ways to monitor correctional staff who sexually abuse offenders. While a few states-Idaho and Florida, for example-discipline and maintain registries of staff, that is not the norm. ${ }^{135}$ Given the portability of corrections as a profession and the ease with which correctional staff move from state to state and from one custodial setting to anotheradult, mentally ill, juvenile, community, private-sex offender registration holds some promise from preventing culpable staff from working in custodial settings with other vulnerable populations.

\section{Duty to Report Sexual Abuse of Offenders}

Under-reporting of staff sexual misconduct within correctional institutions creates environments where misconduct can flourish. States should include duty to report provisions in their staff sexual misconduct laws. However, if 'duty to report' clauses are enacted, companion provisions prohibiting retaliation against those who report should also be included. When offenders or staff members fear retaliation for reporting incidents, they may forego reporting altogether. ${ }^{136}$ Appropriate legal protections can empower offenders and staff, providing some assurance that they are less vulnerable after filing a report. Four states-Florida, Maine, 
Missouri and South Carolina-all include duty to report clauses. ${ }^{137}$ In addition, Florida, Missouri and South Carolina also provide for protection from retaliation for those who report incidents of staff sexual misconduct.

The Florida law provides that any employee who witnesses, or has reasonable cause to suspect, that an inmate or an offender is the subject of sexual misconduct must immediately prepare, date, and sign an independent report. ${ }^{138}$ It also provides that "any person who knowingly or willfully coerces or threatens any other person with the intent to alter either testimony or a written report regarding an incident of sexual misconduct." ${ }^{139}$ Failure to report an incident of staff sexual misconduct is a first degree misdemeanor punishable by imprisonment for no more than one year. Coercing or threatening someone reporting sexual abuse is a third degree felony punishable by imprisonment not to exceed five years. ${ }^{140}$

Maine law provides that a person is guilty of failure to report sexual assault of a person in custody if that person is a member of the staff, knows that a person was sexually assaulted, and does not report it to the appropriate criminal justice agency. Failure to report is a Class E crime punishable by up to six months imprisonment. ${ }^{141}$

Missouri law provides that when any employee of the department has reasonable cause to believe that an offender has been abused, he must immediately report it in writing to the director ${ }^{142}$ Failure to report is a Class A misdemeanor punishable by up to one year imprisonment and a $\$ 1,000$ fine. ${ }^{143}$ The law also provides that "no person who directs or exercises authority in a correctional center operated or funded by the department shall harass, dismiss, or retaliate against an offendervictim or employee because he or any member of his family has made a report of any violation or suspected violation of laws, ordinances, or regulations applying to the correctional center which he has reasonable cause to believe has been committed or occurred." ${ }^{144}$

In South Carolina, the law holds that "a person who has knowledge of sexual misconduct who has received information in the person's professional capacity and fails to report it to the appropriate law enforcement authority, or a person who threatens or attempts to intimidate a witness "is guilty of a misdemeanor ${ }^{145}$ punishable by up to one year imprisonment." ${ }^{146}$

\section{Mandatory Reporting: Juvenile and Vulnerable Persons}

Although often outside the scope of staff sexual misconduct laws, there are special reporting provisions available in the event of abuse of juveniles and/or vulnerable persons. Mandatory reporting specifically requires certain individuals to report cases of physical or sexual abuse committed against children and vulnerable persons. All 50 states and the District of Columbia have mandatory reporting laws for youth and 49 states and the District of Columbia have mandatory reporting laws for vulnerable persons. ${ }^{147}$

Currently only 26 states include correctional staff as mandatory reporters for abuse of children and vulnerable adults. ${ }^{148}$ Hawaii and Mississippi explicitly name correctional staff in their law while the other 24 states imply it by stating "any person" or "all people". ${ }^{19}$ Hawaii law is very specific and states that a mandatory reporter in the performance of their professional or official duties who has reason to believe child abuse or neglect or abuse of a dependent adult has occurred must report the abuse. The law specifically includes "employees or officers of any law enforcement including, but not limited to, the courts, police departments, correctional institutions, and parole or probation offices." ${ }^{150}$ Other states such as Maine are more general defining mandatory reporters as "any person who has assumed full, intermittent or occasional -responsibility for the care or custody of the incapacitated or dependent adult." ${ }^{151}$

\section{Licensing}

Staff members convicted of staff sexual misconduct may also lose their professional licenses or certifications. Many states require that correctional officers and administrators be licensed or certified. ${ }^{152}$ In Wyoming, for example, correctional officers are considered peace officers. Officers must complete Peace Officer Standard Training within their first year to become licensed, however the department director by statue can then recommend revokation of the license for any official misconduct. ${ }^{153}$

Moreover, many other staff who work in correctional facilities must be licensed in order to practice, including medical personnel (nurses, doctors, technicians), psychologists, lawyers, social work professionals, barbers, child care professionals, and educators. Most 
states have provisions to revoke licenses for these professionals in cases of sexual abuse. A criminal conviction or administrative sanction may result in proceedings to strip these individuals of their professional licenses, thereby limiting their future employability in their field.

\section{The Impact of PREA on State Laws}

Since the passage of PREA, two states-California and Texas-have passed laws implementing PREA. The California law provides: inmates and wards with informational handbooks regarding sexual abuse in detention; adopts specified policies, practices, and protocols related to the placement of inmates, physical and mental health care of inmate victims, and investigation of sexual abuse; accurate data collection concerning sexual abuse across all institutions which is accessible to the public; and develops guidelines for the provision of resources and counseling from outside organizations to inmates and wards. The law also allows for the creation of the Office of the Sexual Abuse in Detention Ombudsperson to ensure confidential reporting and impartial resolution of sexual abuse complaints in CDCR facilities. ${ }^{154}$
Texas House Bill 1944 was passed in 2007 and creates a position of ombudsperson in the Office of the Inspector General to monitor prevention and investigation policies to ensure impartial resolution of inmate complaints of sexual assault; authorizes the ombudsperson to collect evidence and interview inmates or employees at correctional facilities in conducting an investigation of an inmate complaint of sexual assault under this section; and prohibits the ombudsperson from requiring an inmate who reports a sexual assault to assist in the investigation or prosecution of the offense. ${ }^{155}$

Clear legislation with appropriate penalties is an effective tool in addressing staff sexual misconduct with offenders. These legal remedies are only effective, however, if incidents are reported, offending staff are penalized, and punishment is certain and substantial. Though most states already have laws prohibiting staff sexual misconduct, the mere existence of a law does not guarantee that the law is being enforced. Strengthening staff sexual misconduct laws, consistent with the purpose and spirit of PREA, will assist states in addressing and preventing this dangerous misconduct. 
LEGAL RESPONSES TO SEXUAL VIOLENCE IN CUSTODY:

STATE CRIMINAL LAWS PROHIBITING STAFF SEXUAL ABUSE OF INDIVIDUALS UNDER CUSTODIAL SUPERVISION 


\section{Conclusion}

However, it is important to remember that state criminal laws prohibiting sexual abuse of persons in custody are not the only tools and remedies that advocates, legpeople in custody are important tools in preventing staff sexual misconduct with persons under custodial supervision. This publication has addressed several of the key issues in analyzing these state laws:

(1) staff sexual misconduct and its definitions;

(2) policy issues that stakeholders and policymakers should consider when evaluating state criminal laws prohibiting sexual abuse in custodial settings; and

(3) recommendations for amending state laws to enhance effectiveness. islators, correctional leaders and offenders have at their disposal. Other tools will be explored in later publications. What is important to remember is that staff sexual misconduct compromises the safety and security of the institution and the public, affecting offenders as well as people in the surrounding communities. It is important that as PREA standards are released that not only are state criminal laws amended to comply with PREA but that agency policies and procedures are developed to address areas that law may not, in order to ensure safe and secure correctional environments and the safety of staff, offenders and the public. 


\section{End Notes}

1. $\quad$ See, The Prison Rape Elimination Act of 2003 [hereinafter "PREA"], 42 U.S.C. § 15604 (2003).

2. See generally, Human Rights Watch, No Escape: Male RAPE IN U.S. PRISONS (2001).

3. See Eric M. Weiss, Corrections Officer Gets Seven Years in Prison, The Washington Post, July 22, 2006 at B04 (reporting that the D.C. Superior Court found Robert White was found guilty of first-degree sexual abuse of a ward for forcing an inmate to perform oral sex on him); News Sentinel Staff, Former Jailer Indicted on Rape Charge; Case Includes Official Misconduct Conduct, KNOxvILLENews SEntinel, March 1, 2006 at B3 (reporting that a former Roane County Sheriff's Department jailer has been indicted on rape and official misconduct charges for the rape of a female inmate at the jail when the corrections officer was on duty); Charlie Frago, Guard-Inmate Sex Investigated Supermax Prisoner Called In Complaint on Hot Line, officials say, ARKANSAs Democrat GazetTe, December 16, 2005 (reporting that a correctional officer at the state's Supermax prison could face felony charges of engaging in sex with an inmate kept in punitive isolation at the highest-security unit in the state); GuardInmate Relationships Lead to Lazesuits, Payouts, TELEGRAPH HERALD, May 22, 2000 at A10 (reporting that sexual encounters between Iowa inmates and their guards are occurring repeatedly and costing taxpayers large payouts in lawsuits); Don Jacobs, Jailer Faces Rape, Sexual Battery Charges; Female Inmate's Two-Page Report Details HoursLong Harassment by Officer, KNOXVILLE-NEws SENTINEL, Aug. 3, 2005 at A1 (reporting on a Know County jailer who fondled inmates and forced them to perform oral sex); Jail Officer Charged with Raping Inmate, THE WASHINGTON POST, August 27, 1997 at B03 (reporting that an officer at a regional jail in Fredericksburg, Virginia was charged with raping a female inmate on work detail); Suit Claims Prison Guard Raped Inmate, THE Associated Press State and Local WIRE, August 15, 1998 (reporting that an inmate alleged that a correctional officer forced the inmate to perform oral sex and raped him).

4. See, Kristy Gillentine, Prison officer chargds in sex with inmate, THE EAGLE, August 17, 2006, available at (reporting that a longtime corrections officer at the Federal Prison Camp in Bryan, Texas was charged with three counts of improper sexual activity with a person in custody); Alan Gustafson, Prison guard is charged with sex misconduct, STATESMan JouRnaL, September 21, 2006, available at (reporting that a male corrections corporal was charged with three counts of first-degree custodial sexual misconduct, a class C felony); Ryan LaFontaine, April Trials Set For Suits Against Jail, The Sun Herald, AUG 19, 2006 (discussing two federal lawsuits against the now-defunct Hancock County Jail where female inmates claimed they were beaten and forced to have sex with guards); Henry K. Lee, Deputy Faces Rights Suit by Former Inmates, He's Accused of Sex 'Torment' When She Was in
County Jail, san Francisco Chronicle, August, 24 , 2006, at B3 (discussing a \$4 million federal civil-rights lawsuit filed by a female inmate who was forced to perform oral sex on a San Francisco sheriff's deputy).

5. See National Institute of Corrections, Dep'T of Justice, Map Representation of State Criminal LaWs Prohibiting SeXual Misconduct with OfFEnders in 1990 [hereinafter "MAP REPRESENTATION OF STATE Criminal Laws Prohibiting Sexual Misconduct with OFFENDERS IN 1990"]; NATIONAL INSTITUTE OF Corrections, Dep’t of Justice, Map Representation of State Criminal Laws Prohibiting Sexual Misconduct with OfFENDERS IN 2009 [hereinafter "Map representation of State Criminal Laws Prohibiting Sexual Misconduct with Offenders in 2009"] (updated under NIC Cooperative Agreement 07S27GJT7).

6. See, e.g., Women Prisoners of the Dist. of Columbia Dep't of Corrections v. Dist. of Columbia, 968 F. Supp. 744 (D.D.C. 1997); Everson v. Michigan Dep’t of Corrections, 391 F.3d 737 (6th Cir. 2005); Cason v. Seckinger, 231 F.3d 777 (11 ${ }^{\text {th }}$ Cir. 2000).

7. Id.

8. $I d$.

9. See generally, PREA, supra note 1 , at $§ 15601$.

10. See generally, Prison Rape Reduction Act of 2003: Hearing on H.R. 1707 Before the S. Comm. on Crime, Terrorism, and Homeland Security of the H. Comm. on the Judiciary, 108th Cong. 4-5 (2003).

11. See generally, California Sexual Abuse in Detention Elimination Act Cal. Penal Code $§ 2635-2643$ (2008) [hereinafter "California Sexual Abuse in Detention Act"]. In 2005, California passed The Sexual Abuse in Detention Elimination Act, which is the first state legislative response to PREA. The purpose of the law is " $[t]$ o protect all inmates and wards from sexual abuse while held in institutions operated by the Department of Corrections and Rehabilitation." The Act includes provisions for: investigating allegations of staff sexual misconduct, training employees, mandatory background checks for DOC employees, providing mandatory inmate information on the subject of sexual abuse while in detention, creation of the Office of the Sexual Abuse in Detention Elimination Ombudsman, development of guidelines allowing outside services (rape crisis, gay rights organizations etc.) to victims, the creation of specific policies regarding placement and health care, and compliance with PREA. See also, H.B. 1944, 2007 Leg., $80^{\text {th }}$ Sess. (Tex 2007) [hereinafter "Texas House Bill.'] The bill authorizes the ombudsperson to collect evidence and interview inmates or employees at correctional facilities in conducting an investigation 
of an inmate complaint of sexual assault under this section and prohibits the ombudsperson from requiring an inmate who reports a sexual assault to assist in the investigation or prosecution of the offense.

12. See, PREA, supra note 1 , at $§ 15609$ (8). The term "prison rape" includes the rape of an inmate in the actual or constructive control of prison officials. PREA further defines prison rape as: "(A) the carnal knowledge, oral sodomy, sexual assault with an object, or sexual fondling of a person, forcibly or against that person's will; (B) the carnal knowledge, oral sodomy, sexual assault with an object, or sexual fondling of a person not forcibly or against the person's will, where the victim is incapable of giving consent because of his or her youth or his or her temporary or permanent mental or physical incapacity; or (C) the carnal knowledge, oral sodomy, sexual assault with an object, or sexual fondling of a person achieved through the exploitation of the fear or threat of physical violence or bodily injury."

13. See, PREA, supra note 1 , at $\S 15609$ (7). The term "prison" means any confinement facility of a Federal, State, or local government, whether administered by such government or by a private organization on behalf of such government including any local jail or police lockup and any juvenile facility used for the custody or care of juvenile inmates.

14. See, PREA, supra note 1 , at $\S 15609(7)$.

15. See, PREA, supra note 1 , at $\S 15603(4)$.

16. See, PREA, supra note 1 , at $\S 15603$.

17. See generally, Bureau of Justice Statistics, U.S. Dep’T OF JusticE, Workshop on Implementation of the Prison Rape Elimination Act of 2003 (2003); see also BUREAU OF JUSTICE Statistics, U.S. Dep'T OF JUSTice, Workshop on Inmate Self-Report of Sexual Assault Victimization, (2005); BUREAU of Justice Statistics, U.S. Dep’t of Justice, Workshop on Prison Rape Elimination Act of 2003: Presenting the National Inmate (2006).

18. See, U.S. Dep’t of Justice, Bureau of Justice Statistics, Data Collections for the Prison Rape Elimination ACT OF 20039 (2006).

19. Id.

20. See, PREA, supra note 1 , at $\S 15602(4)(5)(6)$

21. See generally, Heather Wes and William Sabol, Bureau of Justice Statistics, Inmates at Midyear 2008: Statistical Tables (2009) [Hereinafter "INMATES AT MidYEAR 2008.”]

22. See, 18 U.S.C.S. § 2246 at "Definitions."

23. Id at \$2241 at "Aggravated Sexual Abuse"
24. Id at $\$ 2241(a)$ at "Aggravated Sexual Abuse by Force or Threat."

25. Id. at $\S 2243$ (amended 2006) (increasing the penalty from one year to five years).

26. Id. at $\S 2243$ (amended 2006) (increasing the penalty from five years to fifteen years).

27. See, National Institute of Corrections, US Dep’t of Justice, [hereinafter "NIC"] WASHINGTON COLLEgE OF LAW [hereinafter "WCL"] ProjeCt ON AdDREsSING Prison Rape Website, End to Silence- Policies and Procedures: StafF Sexual Misconduct (developed under NIC Cooperative Agreement 06S20GJJ1) (2006) available at.

http://www.wcl.american.edu/nic/policies.cfm\#ssm; see also, Arlington County Detention Facility, Sexual Misconduct Brochure (2000); Cal. Dept. of Corr., Sexual Abuse/Assault Prevention and Intervention: An Overview For OfFEnders, KNow Your Rights \& Responsibilities (2000); Federal Bureau of Prisons, U.S. Dep't of Justice, Sexually Abusive Behavior PREVENTION AND INTERVENTION PROGRAM 4 (2005), available at

http://www.bop.gov/DataSource/execute/dsPolicyLoc.

28. Id.

29. See, Prison Inmates at Midyear 2008, supra note 21.

30. Id. See also, Todd D. Minton \& William J. Sabol, Bureau of Justice Statistics, Jail InMates at Midyear 2008: Statistical Tables (2009); LaUREN E. Glaze \& Thomas P. Bonczar, Bureau of Justice Statistics, Probation and Parole in the United States: Statistical Tables, 2007 (2008). The number of inmates in custody and the number of offenders on probation and parole, when combined from the two studies equal the statistic above. Please note: there may be some overlap in the two statistics when added together because it is possible that people were held in prisons or jails as well as paroled in the same year-thereby counting twice in this statistic.

31. See, NiC/WCL Project on Addressing Prison Rape, Fifty State Survey of Official Misconduct Statutes (2009).

32. See, NIC/WCL Project on Addressing Prison Rape, Fifty State Survey of State Licensing REQUiREMENTS (forthcoming) [hereinafter "FIFTy STATE SuRvey of State Licensing ReQUiREMENTS."]

33. See, NIC/WCL Project on Addressing Prison Rape, Fifty State Survey of Adult Sex Offender REgISTRATION REQUIREMENTS (2009) [hereinafter "FIFTY State Survey of Adult Sex Offender Registration REQUIREMENTS."]

34. See, Office of the Inspector General, U.S. Dep’t of Justice, Deterring Staff Sexual Abuse of Federal InMATES (2005) [hereinafter "DeterRing SEXUAL Abuse of FedERAL InMATES.”] 
35. See, Map representation of State Criminal Laws Prohibiting SeXual Misconduct with OfFenders in 1990 supra note 5.

36. See. Map Representation of State Criminal LaWs Prohibiting Sexual Misconduct with OfFEnders in 2009 supra note 5.

37. See, NiC/WCL Project on Addressing Prison Rape, Fifty State Survey of STATE CRIMINAL LAWS PROHIBITING THE SEXUAL ABUSE OF INDIVIDUALS IN CUSTODY (2009) hereinafter "FifTy STATE SURVEY OF STATE CRIMINAL Laws Prohibiting sexual Abuse."]; See also, Brenda V. Smith, Professor and NIC Program Director, Washington College of Law, Testimony in Support of Maryland House Bill 456 Before the Maryland House Judicial Proceedings Committee (Feb. 15, 2006), available at http://www.nicic.org/Library/021628 (supporting amendments to Maryland's staff sexual misconduct law and penalty enhancements); Tennessee amended their staff sexual misconduct law in 2006, elevating the penalty from a misdemeanor to a felony; 2006 Ten. PUB. CHAPT. 1005 (2006); Gary Susswein, Sexual contact With Inmates by Guards is Now a Felony, The PATriot Ledger, November 18, 1999 at 11 (reporting that Massachusetts amended their staff sexual misconduct law from a misdemeanor to a felony).

38. See, e.g., Delaware (Del. CoDE ANN. tit 11, $\$ 1259$ (West 2008)); Kentucky (Ky. Rev. STAT. ANN. § 510.120 (West 2008)); and Massachusetts (Mass. AnN. Laws ch. 268, § 21A (West 2008)).

39. See, N.M. Stat. Ann. § 30-9-11 E(2) (West 2008).

40. See, Del. Code Ann. tit. 11, § 1259 (West 2008). Sexual relations in detention facility; class $\mathrm{G}$ felony.

41. See, NiC/WCL Project on Addressing Prison Rape, U.S. Department of Justice, National Institute of Corrections. Fifty State Survey of State Run Adult Community Corrections Programs. (2006).

42. Id.

43. Id

44. See, Nev. Rev. Stat. Ann. § 212.187 (West 2008). Voluntary sexual conduct between prisoner and another person; penalty.

45. See, Elain Rivera, Ex-Deputy Guitly of Having Sex With Inmates, THE WASHINGTON POST, February 25, 2004 at B3 (reporting that a sheriff's deputy abused his authority to extract sex from two women who were in a work-release program that the deputy was assigned to and stating that the women felt that they had to comply with the deputy's sexual demands to stay in the program); Karen McDonald, Conduct may cost officer his job, Handegan admitted having sex with convicted felon, THE JOURNAL STAR, August 7, 2006 (reporting that a Tazewell County correctional officer may lose his job for having sex with a convicted felon after she was released from jail); Beverly Wang, Court papers report ex-sergeant repeatedly assaulted inmates, THE Associated PRess STATE AND Local Wire, January 13, 2006 (reporting that a former corrections sergeant was accused of repeatedly raping and assaulting four women inmates under his supervision at a halfway house); Beaver Utah, Second deputy sentenced for sex with inmate, probationer, THE Associated PREss STATE AND LOCAL WIRE, July 20, 2006 (sentencing a second former Washington County sheriff's deputy to 120 days for having sex with a woman on probation).

46. See, Fifty State Survey of State Criminal Laws Prohibiting the SeXual Abuse, supra note 37.

47. See, Wis. Stat. Ann. § 940.225 (2)(I) (West 2008).

48. See, Ga. Code AnN. § 16-6-5.1 (West 2008).

49. See, Ala. Code $§ 14-11-30$ (West 2008); 720 ILl. Comp. Stat. Ann. § 5/11-9.2 (West 2008); Tenn. Code Ann. § 39- 16-601 (West 2008).

50. See, Kan. Stat. Ann. § 21-3520 (West 2008); Me. Rev. Stat. AnN. tit. 17-A, § 260(1)(E) (West 2008).

51. See, Jeffrey Birnbaum, Foley Dredges Up Scandal Problems for GOP, The Washington POST, Oct. 11, 2006 available at ; Allison Klein \& Henri E. Cauvin, Sex Offender Admits Killing Teen in NE: Man, 51, on parole after 70's Md. Rape, The Washington Post, Sept. 28, 2006, at B02; Robert MacMillan, Sex Offender Lists Fall Short, THE WASHINGTON POST, May 26, 2005 available at http://www.washingtonpost.com/wpdyn/content/article/2006/09/27/AR2006092700420_pf. html.

52. See, Adam Walsh Act, Pub. L. No. 109-248 § 120 Stat. 588 (2006) [hereinafter "Adam Walsh Act"].

53. See, Smith Consulting, National Institute of Corrections, US DepartMent of Justice, News Stories: Sexual Abuse of Youth in Custody (June 2007). See also, Alicia Caldwell, 2 former Texas Youth Commission administrators indicted on sex abuse charges NAPA Valley Register, April 11, 2007; Dana Wilson, Ex-prison guard convicted of assaulting teenage inmate, THE COLUMBUS Dispatch, March 17, 2006; Rick Anderson, A sex scandal widens among guards at the county and juvenile jail, SEATTLE WeEkLY, August 2, 2006; Associated Press, Former Juvenile Center Guard pleads to Misconduct September 15, 2006; Hearing Before the National Prison Rape Elimination Commission (June 1, 2006) (testimony of Carl Brizzi), available at http://nprec.us/proceedings_boston.htm (last visited September 9, 2008).

54. See, e.g., generally, Human Rights Watch AND AMERICAN Civil Liberties union, Custody and Control, CONDITiOnS OF CONFINEMENT IN NeW York's Juvenile PRISONS FOR GIRLS 63-71 (2006) (describing the sexual 
exploitation of juvenile girls by staff members in the New York Juvenile Justice System); STOP Prisoner RAPE, FACT SHEET: InCARCERATED Youth at EXTREME RisK of SEXUAL Assault (2007) available at: http://spr.org/en/factsheets/Youth.pdf); STOP PRISONER RAPE, In THEIR OWN WoRds: RECENT EXAMPLES OF Sexual Abuse of Youth Behind Bars (2006) available at: http://spr.org/pdf/prea_update_june_06.pdf; ALLEN Beck et al., Bureau of Justice Statistics, The Prison Rape Elimination Act of 2003: Sexual Violence Reported by Juvenile Correctional Authorities, 2005-06 (2008); US Department of Justice, CiviL Rights Division, CRIPA Findings: INVESTIGATION OF THE CheltcNham Youth Facility and ChaRles H. HickeY, JR. SCHOOL IN MARYLAND (2004); US Department of Justice, Civil Rights Division, CRIPA FINDINGS: INVESTIGATION OF THE CONDITIONS AT THE King County CoRrectional Facility (2007).

55. See, Allen J. Beck \& Timothy A. Hughes, Bureau of Justice Statistics, Sexual violence Reported by CORRECTIONAL Authorities 2004 (2005) [hereinafter "Sexual Violence Reported by Correctional Authorities"]. A number of factors contribute to these statistics. First, because juvenile agencies are required by law to report any abuse or neglect, these agencies have better-developed mechanisms for reporting abuse. Second, unlike adults, juveniles' cases are reviewed regularly, giving juveniles ongoing access to the courts. Incidents are thus more likely to come to the attention of supervising authorities. Finally, many juveniles have regular contact with lawyers and parents to whom they may reveal such incidents.

56. See, Allen J. Beck, Devon Adams, and Paul Guerino, Bureau of Justice Statistics, Sexual violence Reported by Juvenile Correctional Authorities 2005-6 (2008).

57. Id. at 2 .

58. Id. at 5 .

59. See, Fifty State Survey of State Criminal Laws Prohibiting the Sexual Abuse, supra note 37.

60. Kan. Stat. AnN. § 21-3520(a) (West 2008).

61. See, Fifty State Survey of State Criminal laws Prohibiting the SeXual Abuse, supra note 37. States that exclude juvenile agencies are: Oregon, Idaho, Nevada, Rhode Island, Vermont, Missouri, Mississippi and South Carolina.

62. R.I. GEN. Laws § 11-25-24 (West 2008).

63. See, Ala. CodE $\S 13 A-6-61$ (West 2008) (age of consent is 16); Ky. Rev. STAT. ANN. $§ 510.020$ (2006) (age of consent is 16$)$.

64. See, NiC/WCL Project on Addressing Prison Rape,
Fifty State Survey of Exploitation of Minors Laws (forthcoming) [hereinafter "SURVEY OF EXPLOITATION OF MinORS LAWs."]

65. See generally, Sexual Violence Reported by CORRECTIONAL Authorities, supra note 55.

66. See generally, Wackenhut Corporation, available at; Corrections Corporation of America, available at www.correctionscorp.com; and Youth Services International, available at www.ysii.com.

67. See, e.g., The Hawaii Department of Corrections (DOC) participates in community service work lines where offenders work for county, state and non-profit organizations. The Hawaii DOC also has the Laumaka Work Furlough Center where offenders work in the community, available at www.hawaii.gov/psd/corr_home.php; See also, The Arkansas Department of Corrections (DOC) has a work release program. The Arkansas DOC work release program provides inmates with community jobs to increase job skills and work role experience prior to release, available at

www.state.ar.us/doc/programs_pg2.html\#release.

68. See, Fifty State Survey of State criminal laws ProHIBITING THE SEXUAL ABUSE OF INDIVIDUALS IN CUSTODY, supra note 37 .

69. See, Ohio Rev. Code Ann. § 2907.03 (West 2008); Ohio Rev. Code ANN. § 2921.01 (West 2008).

70. See, N.D. CENT. CODE $§ 12.1-20-07$ (West 2008).

71. See, SeXual violence Reported by Correctional AUTHORITIES, supra note 55.

72. See generally, Richardson v McKnight, 521 U.S. 399 (1997) (finding private employment guards are not entitled to qualified immunity from inmate's tort claims).

73. See generally, Brenda V. Smith and Jaime M. Yarussi, Breaking the Code of Silence: A Correction OfFicers' Handbook on IDENTIFying and AdDressing Staff Sexual Misconduct with Offenders (2007).

74. See, Charlie Frago, Sex With Inmate Costs Prison Psychologist Job Cummins Unit Tryst Under Investigation, ARKANSAS DEMOCRAT GazeTte, April 21, 2006 (reporting that a prison psychologist has been fired after being found having sex with an inmate in her office at the Cummins Unit).

75. See, Melvin Claxton, Ronald J. Hansen, and Norman Sinclair, Guards Assault Female Inmates, The DetroIt News, May 22, 2005 (reporting that an inmate at the Huron Valley complex in Ypsilanti was raped in a storage room by a prison maintenance worker).

76. See, Owen Covington, Jail Worker Charged With Misconduct: Woman is Accused of Performing Oral Sex on an 
Inmate, Kinght/Ridder Tribune News Service, August 2, 2006 (reporting that a medical technician for the Daviess County Detention Center was arrested Tuesday and is accused of having an ongoing sexual relationship with an inmate at the jail).

77. See, Counselor Accused of Sex with Inmate, Tribune-Review, August 24, 2006 (reporting that a drug and alcohol counselor was criminally charged with one count of institutional sexual assault after allegedly having sexual encounters with an inmate at the State Correctional Institution at Greensburg). See also, Brenda V. SMITH \& JaIme M. Yarussi, NIC/WCL Project on AdDressing Prison Rape, Addressing Staff Sexual Misconduct with OFFENDERS: CURRICULUM GUIDE 2004 (2005); BREAKING THe Code of Silence Handbook, supra note 73.

78. See, Fifty State Survey of State Criminal Laws Prohibiting the Sexual Abuse, supra note 37.

79. See, 18 Pa. Cons. STAT. $§ 3124.2$ (A) (West 2008)

80. See, N.Y. Penal LaW $§ 130.20$ (McKinney 2008).

81. Id.

82. See, Ky. Rev. Stat. § 510.120(1) (West 2008).

83. See,Tex. Penal Code Ann. 39.04(E) (West 2008).

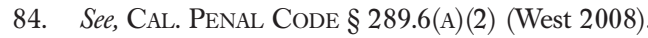

85. See generally, NIC/ WCL Project on Addressing Prison Rape, Training Sessions held under NIC Cooperative Agreements 05S17GJE8, 06S20GJJ1, 07S24GJQ1, 07S25GJQ5 and 07S27GJT7. Training participants noted that often volunteers have the most intimate contact with offenders- most agencies have chaplains, teachers and counselors in a volunteer position. They states that they had problems prosecuting volunteers for staff sexual misconduct with offenders because they are by and are a group not covered by the law in many states. In addition they most often allowed volunteers to simply stop volunteering and leave the facility instead of prosecuting thereby leaving the agency open to civil litigation without being able to seek recourse with the volunteer through prosecution.

86. See, Fifty State Survey of State Criminal Laws Prohibiting the SeXUal Abuse, supra note 37.

87. See, Iowa Code $\S 709.16$ (West 2008); Minn. Stat. $\S \S$ 609.344(1)(m) \& 609.345(1)(m) (West 2008); S.C. CODE ANN. §§ 44-23-1150(A)(1), (B) \& (D) (West 2008).

88. See, Fifty State Survey of state criminal laws ProHIBITING THE SEXUAL ABUSE OF INDIVIDUALS IN CUSTODY, supra note 37. Examples include Connecticut, Maine and New Mexico.

89. See, Fifty State Survey of State criminal laws PRO-
HIBITING THE SEXUAL ABUSE OF INDIVIDUALS IN CUSTODY, supra note 37 .

90. See, Miss. Code AnN. § 97-3-104 (West 2008).

91. See, Ky. Rev. Stat. § 510.010 (West 2008).

92. See generally, Riley v Olk Long, 282 F.3d 592 (8th Cir. 2002).

93. See, Adam Walsh Act, supra note 52.

94. See, Adam Walsh Act, supra note 52 at $\S 111$. Relevant definitions, including Amie Zyla expansion of sex offender definition and expanded inclusion of child predators.

95. See, Adam Walsh Act, supra note 52 at $\S \S 501-507$.

96. Id.

97. See, Fifty State Survey of State Criminal Laws Prohibiting the Sexual Abuse of Individuals in CusTODY, supra note 37.

98. See, Ala. Code $§ 26-14-1$ (West 2008); N.J. STAT. § 9:6-1 (West 2008).

99. See, Alaska Stat. $§ 11.41 .410$ (West 2008); Alaska Stat. $\S 11.41 .420$ (West 2008).

100. See, Del. Code. Ann. tit. 11, § 1259 (West 2008); Nev. Rev. Stat. Ann. § 212.187 (West 2008).

101. See, Lou Grieco and Lawrence Budd, Few Reports, Fear of Reprisal Make It Hard to Say How Often Inmates, Guards Have Sex, Associated PREss, October 15, 2006. See, NIC/WCL Project on Addressing Prison RaPe, Improving Prosecutions of Allegations of SeXual Abuse in Correctional Settings: A Meeting with FEDERAL Prosecutors (October 13, 2006) (attendance list on file with author) [hereinafter "FEDERAL MEETING"].

102. See, Carrigan v. Davis, 70 F. Supp. 2d 448, $452-453$ (D. Del. 1999)(concluding, "as a matter of law, that an act of vaginal intercourse and/or fellatio between a prison inmate and a prison guard, whether consensual or not, is a per se violation of the Eighth Amendment); Fisher v. Goord, 981 F. Supp. 140, 172 (W.D. N.Y. 1997) (recognizing that "sexual interactions between correction officers and inmates, no matter how voluntary, are totally incompatible with the order and discipline required in a prison setting and expressing concern over "the notion that an inmate might feel compelled to perform sexual favors for correction officers in order to be on the officer's "good side”); Barbara Owens and James Wells, National Institute OF CORRECTIONS \& THE MOSS GRoup INC., U.S. Dep’T of Justice, StafF PERSPECTIVES, SeXual Violence in Adult PRisons \& JaILs, TRENDS From FOCUS GROUP INTERVIEWS 7 (2006)(reporting that correc- 
tional staff felt that most sexual assaults were about power than sexual gratification and that "power, control, and violence" were a common theme to obtain sex); Susan W. MCCAMPBELl AND LARRY S. Fischer, NATIONAL InSTITUTE OF CORRECTIONS, U.S. DEP’T OF Justice, Policy Development Guide For Sheriffs And JAIL Administrators (2002)(stating that sexual misconduct is more about the exercise of "power" than the sex act); Peter K. Westen, Some Common Confusions About Consent in Rape Cases, 2 OHIO ST. J. OF CRIM. L. 333, 335 (2004) (contrasting "factual" versus "legal" consent, and indicating that the former is determined by what a jurisdiction deems is sufficient to constitute a defense to rape). See also, Boddie v. Schnieder, 105 F.3d 857, 861 (2d Cir. 1997) (stating that sexual abuse of a prisoner violates contemporary standards of decency, can cause severe physical and psychological harm and has no legitimate penological objective). But see, Phillips v. Bird, U.S. Dist. No. 03-247-KAJ, Westlaw 22953175 (D. Del) (Dec. 10, 2003) (declaring that " $[\mathrm{c}]$ onsensual sex between two adults does not constitute cruel and unusual punishment simply because it occurs within the walls of a prison").

103. Former prison guard sentenced to five years, THE ASSOCIATED Press State \& Local Wire, July 15, 2006.

104. Id.

105. See, Brenda V. Smith, Rethinking Prison Sex: Self-Expression and Safety, 15 Columb. J. OF GENDER \& L. 185 (2006); see also Brenda V. Smith, Continuum of Sexual Behavior in Institutional Settings, developed under NIC Cooperative Agreement 06S20GJJ1 (PowerPoint presentation on file with author) (outlining the continuum of sexual behavior in prisons).

106. See, Survey of Exploitation of Minors Laws, supra note 64 .

107. See, Fifty State Survey of State Criminal Laws Prohibiting the Sexual Abuse, supra note 37

108. See, VA. Code. Ann. § 18.2-64.2 (West 2008).

109. See, Brenda V. Smith and Nairi Simonian, NiC/WCL Project Addressing Prison Rape, A memo Regarding ANTI-Fraternization POLICIES AND CASE LAW IN THE NinTH CIRCUIT (2006) [hereinafter "ANTIFRATERNIZATION MEMO"].

110. See, Fifty State Survey of State criminal laws ProHIBITING THE SEXUAL ABUSE OF INDIVIDUALS IN CUSTODY, supra note 37 .

111. See, Alaska Stat. 11.41.432 (a)(2) (West 2008).

112. See, N.J. Rev. Stat. Ann. 2C:14-5(b) (West 2008). "No actor shall be incapable of committing a crime under this chapter because of age or impotency or marriage to the victim."
113. See, Antifraternization Memo, supra note 109.

114. See, Del. Code. Ann. tit. 11, § 1259 (West 2008).

115. See, Nev. Rev. Stat. Ann. $§ 212.187$ (West 2008).

116. See, Deterring Staff Sexual Abuse of Federal INMATES, supra note 34; OFFICE OF THE INSPECTOR General, U.S. Dep’t of Justice, The Department of Justice's Efforts to Prevent Staff Sexual Abuse of FEDERAL INMATES (2009) hereinafter "EFForTs to Prevent Sexual Abuse”] See also, National Prison Rape Elimination Commission Hearings, "Reporting, Investigating and Prosecuting Prison Rape: What is Needed To Make The Process Work?” Detroit, Michigan (August 3, 2006) [hereinafter "Reporting, Investigating and Prosecuting Prison Rape"] available at http://nprec.us/proceedings_detroit.htm.

117. See, Deterring Staff Sexual Abuse, supra note 34 , at 8 (addressing the issue of prosecuting cases of staff sexual misconduct in federal prisons and subsequently federal law was amended to increase the penalty for staff sexual misconduct in federal prisons from a misdemeanor to a felony).

118. See, Fifty State Survey of State criminal laws ProHIBITING THE SEXUAL ABUSE OF INDIVIDUALS IN CUSTODY, supra note 37.

119. See, Iowa CODE $§ 709.16(2)$ (West 2008).

120. See, Ky. Rev. Stat. § 510.120(1) (West 2008).

121. See, Md. Code Ann., Crim. LaW § 3-314(B) (West 2008).

122. See, Deterring Staff SeXual Abuse, supra note 34.

123. Id.

124. Id.

125. See, Fifty State Survey of State criminal laws ProHIBITING THE SEXUAL ABUSE OF INDIVIDUALS IN CUSTODY, supra note 37.

126. Id.

127. $I d$.

128. $I d$.

129. See, Conn. Gen. Stat. § 53a-71 (West 2008).

130. See, Deterring Staff Sexual Abuse supra note 34; Efforts to Prevent SeXual Abuse supra note 116; Reporting, Investigating and Prosecuting Prison Rape supra note 116. See also, Brenda V. Smith and Jaime M. Yarussi, Prosecuting Sexual Violence in Correctional Settings: Examining Prosecutor's Perceptions, 3 AM. U. CRIM. LAW 
Brief, 19-28 (Spring 2008); Federal MeEting, supra note 97; NIC/WCL Project on Addressing Prison Rape. Improving Prosecutions of Allegations of SEXual Abuse in Correctional Settings: A MeEting with State Prosecutors (October 27, 2006) under NIC Cooperative Agreements 06S20GJJ1 (attendance list on file with author) [ hereinafter "State MEeting"].

131. Id.

132. See generally, Denise Raymo, Franklin County Jail guard charged with sex abuse: Probe says county $C O$ had sex contact with inmate, THE PREss RePUBLICAN, May 7, 2009 available at

http://www.pressrepublcan.com/homepage/local_story_ 127221429.html; Four Corrections Officers Face Obstruction, Force Counts, NorTh COUnTRY GaZETTE, November 24, 2008, available at http://www.wcl.american.edu/nic/AnEndtoSilenceYearin News2008.cfm; Denise Heilbrun, Two others face trial in Platte jail sex case, STAR TRIBUne, September

133. See, Fifty State Survey of Adult Sex Offender REGISTRATION REQUIREMENTS supra note 33.

134. Id.

135. Id. But see, e.g., Russell Stearns v. Gregoire, 124 F.3d 1079 (9th Cir. 1997) (registration and notification are not punitive); Doe v. Pataki, 120 F.3d 1263, 1284-1285 (2d Cir. 1997) (registration and notification are not punitive); E.B. and W.P. v. Verniero, 119 F.3d 1077 (3d Cir. 1997) (notification not punitive, and registration not punitive by implication).

136. See, Melvin Claxton, Ronald J. Hansen and Norman Sinclair, Guards Assault Female Inmates, THE DetroIt News, May 22, 2005 (reporting that inmates say they are too afraid of retaliation from guards and staff to file sexual abuse complaints and that inmates who do report receive misconduct tickets and serve years in extra time).

137. See, Fifty State Survey of State criminal laws ProHIBITING THE SEXUAL ABUSE OF INDIVIDUALS IN CUSTODY, supra note 37 .

138. See, Fla. Stat. AnN. § 944.35 (West 2008).
139. $I d$.

140. Id.

141. See, Me. Rev. Stat. AnN. tit. 17-A, § 760 (West 2008).

142. See, Mo. Rev. Stat. § 217.410 (West 2008).

143. $I d$.

144. Id.

145. See, S.C. Code AnN. § 44-23-1150 (West 2008).

146. $I d$.

147. See, NIC/ WCL Project on Addressing Prison Rape, Fifty State Survey of state Mandatory Reporting LAws (2009). The only state with no mandatory reporting statute on abuse of vulnerable adults is South Dakota.

148. Id.

149. Id.

150. See, Haw. Rev. Stat. Ann. § 346-224 (West 2008); Haw. Rev. Stat. Ann. § 346-224 (West 2008). Haw. Rev. Stat. Ann. § 350-1.1 (West 2008); Haw. Rev. Stat. AnN. § 3501.1 (West 2008).

151. See, Me. Rev. Stat. Ann. tit. 22 § 3477 (1)(a)(1)-(23) (West 2008)

152. See, NiC/WCL Project on Addressing Prison Rape, Fifty State Survey of State Licensing Requirements (forthcoming).

153. Id. See, Wyo. Stat. AnN. § 1977, and §§ 9-1-701 through 9-1-710 (West 2008) (addressing Peace Officers' certification).

154. See, California Sexual Abuse in Detention Elimination Act, supra note 11.

155. See, Texas House Bill, supra note 11. 


\section{Appendix}

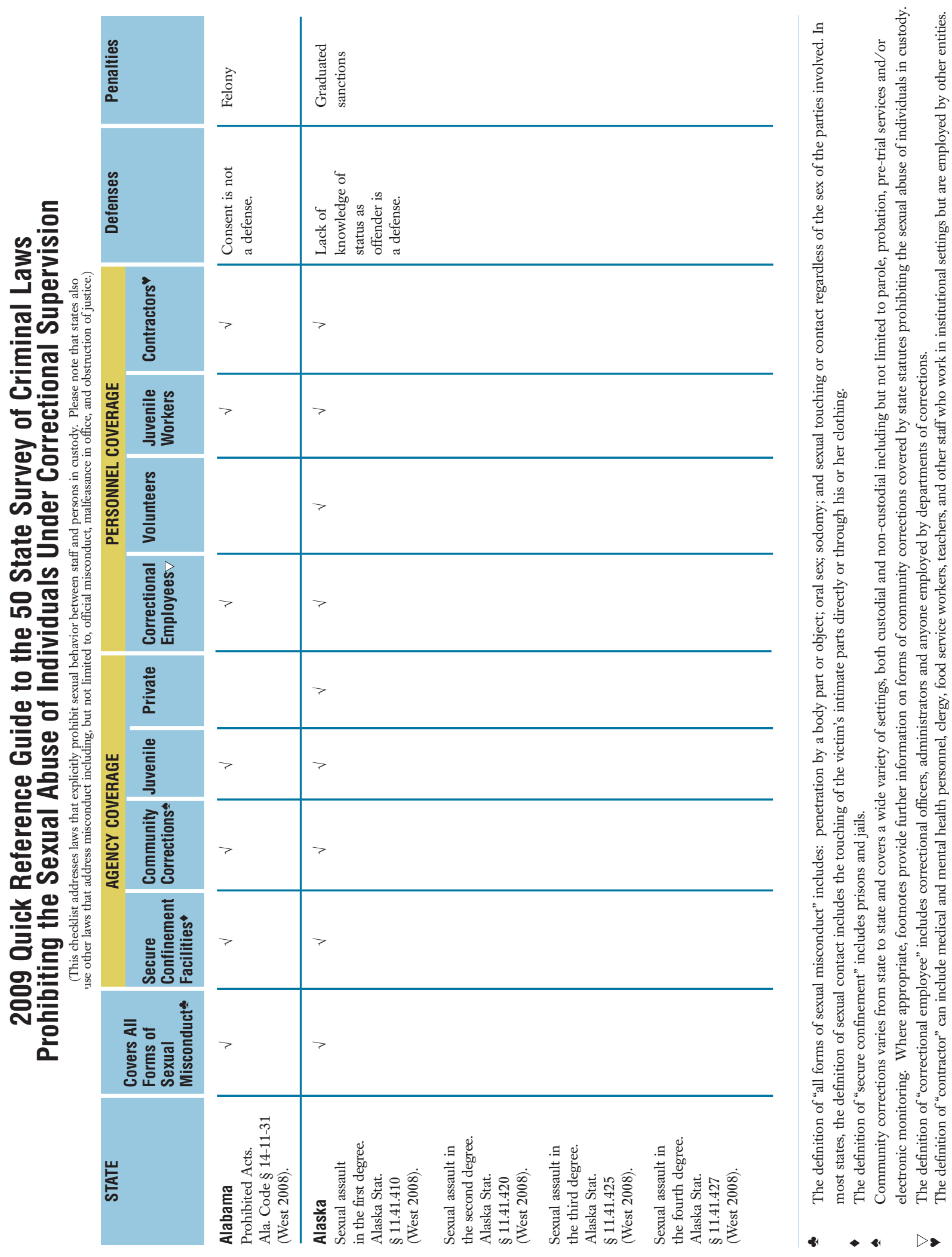




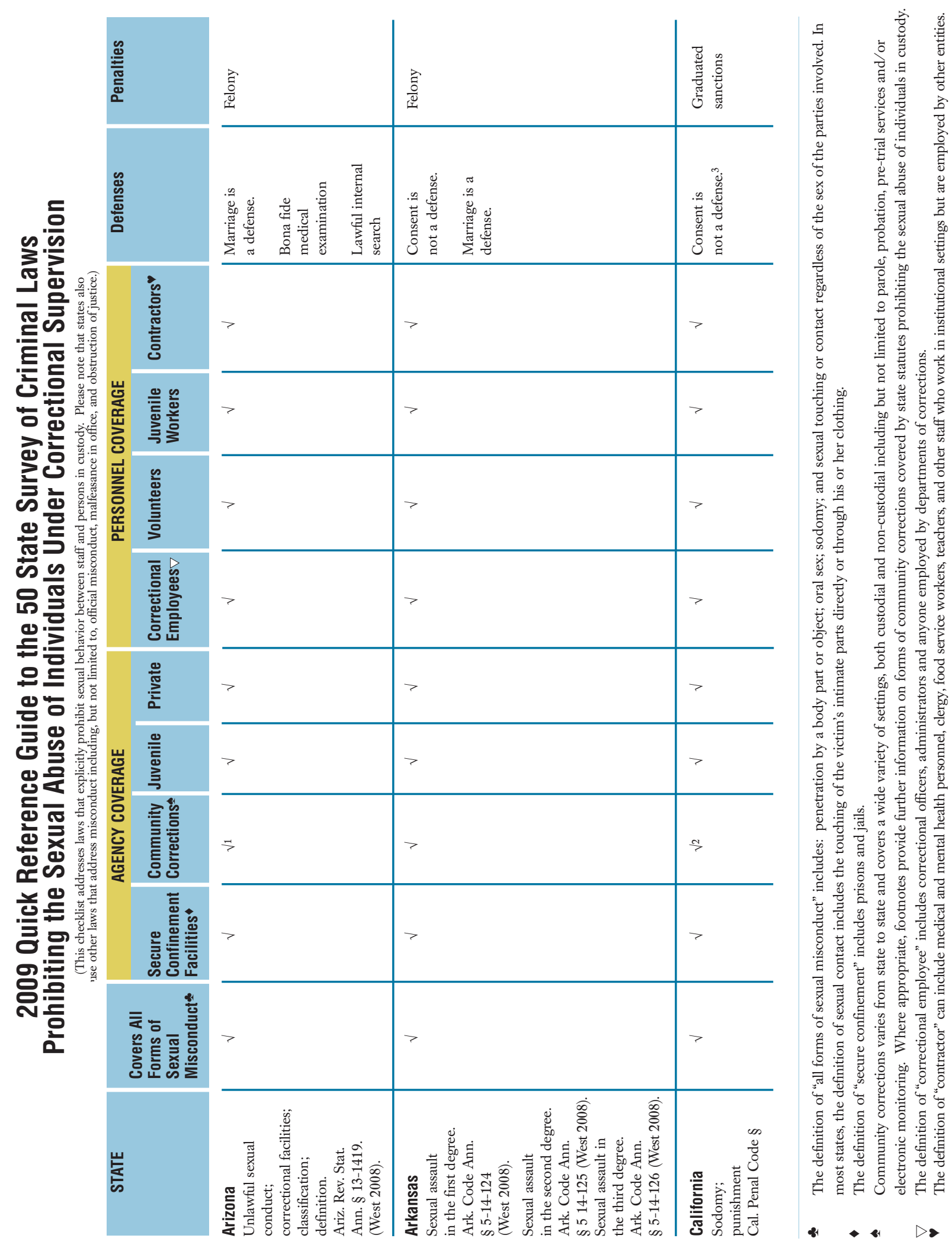




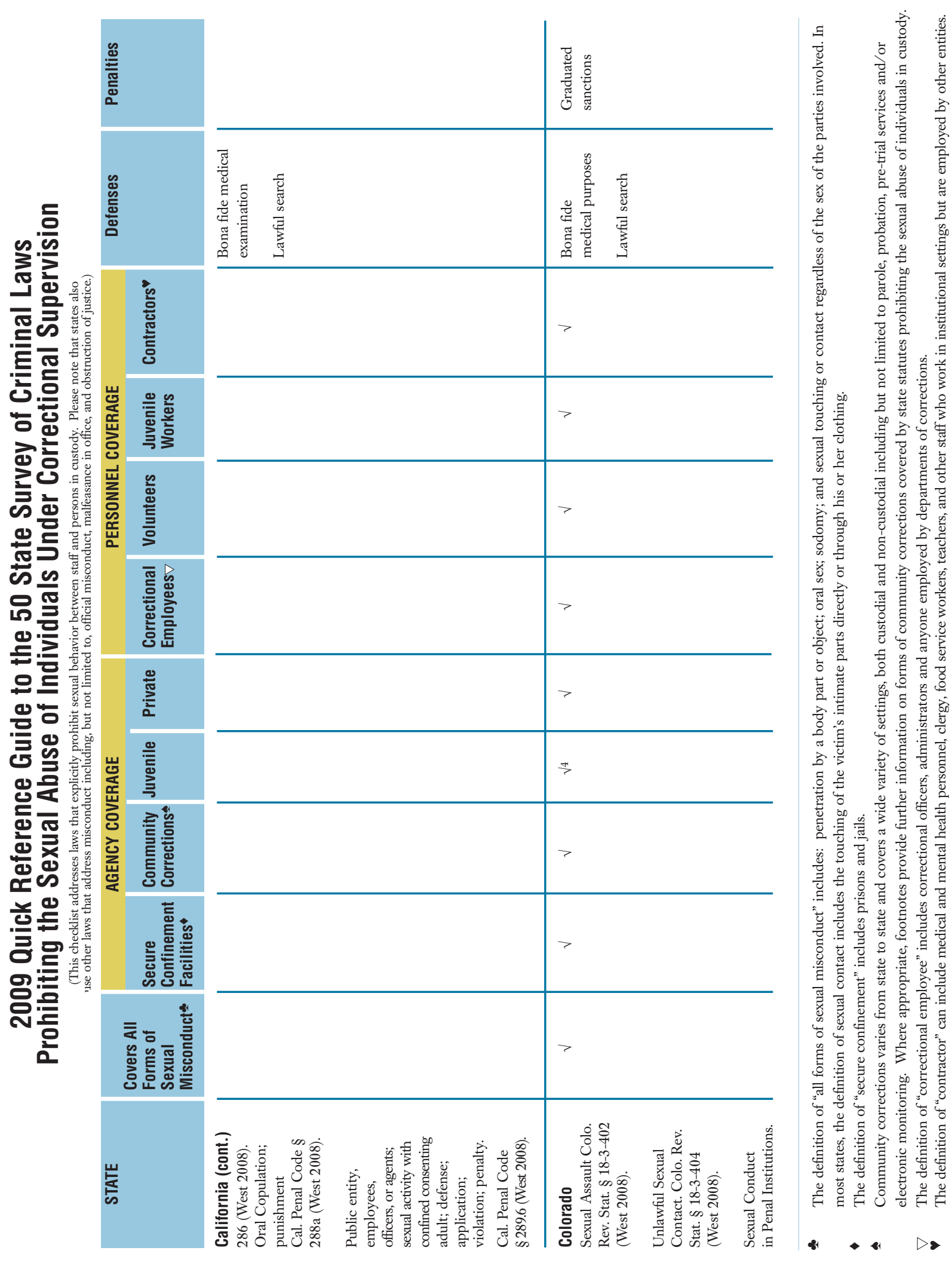




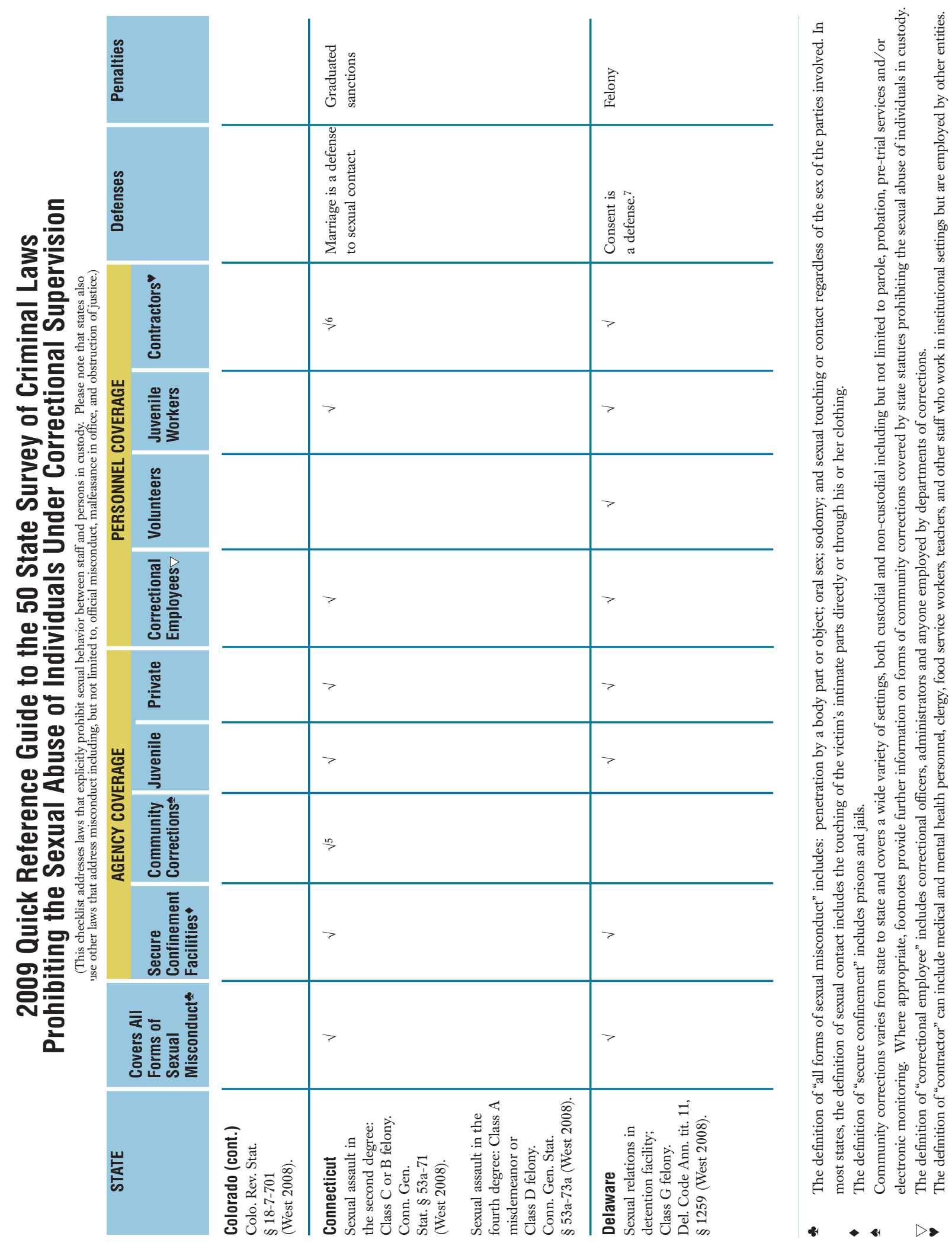




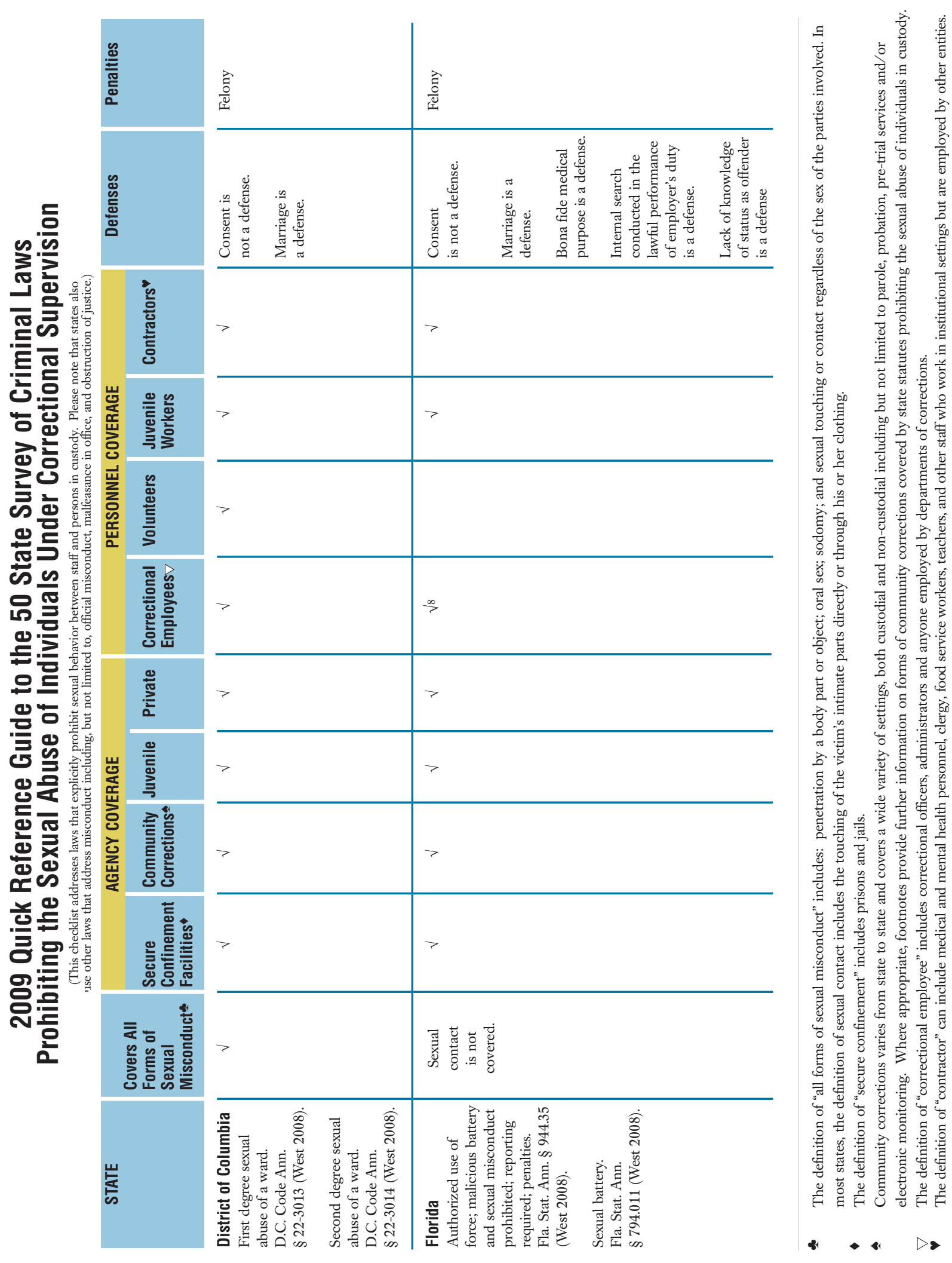




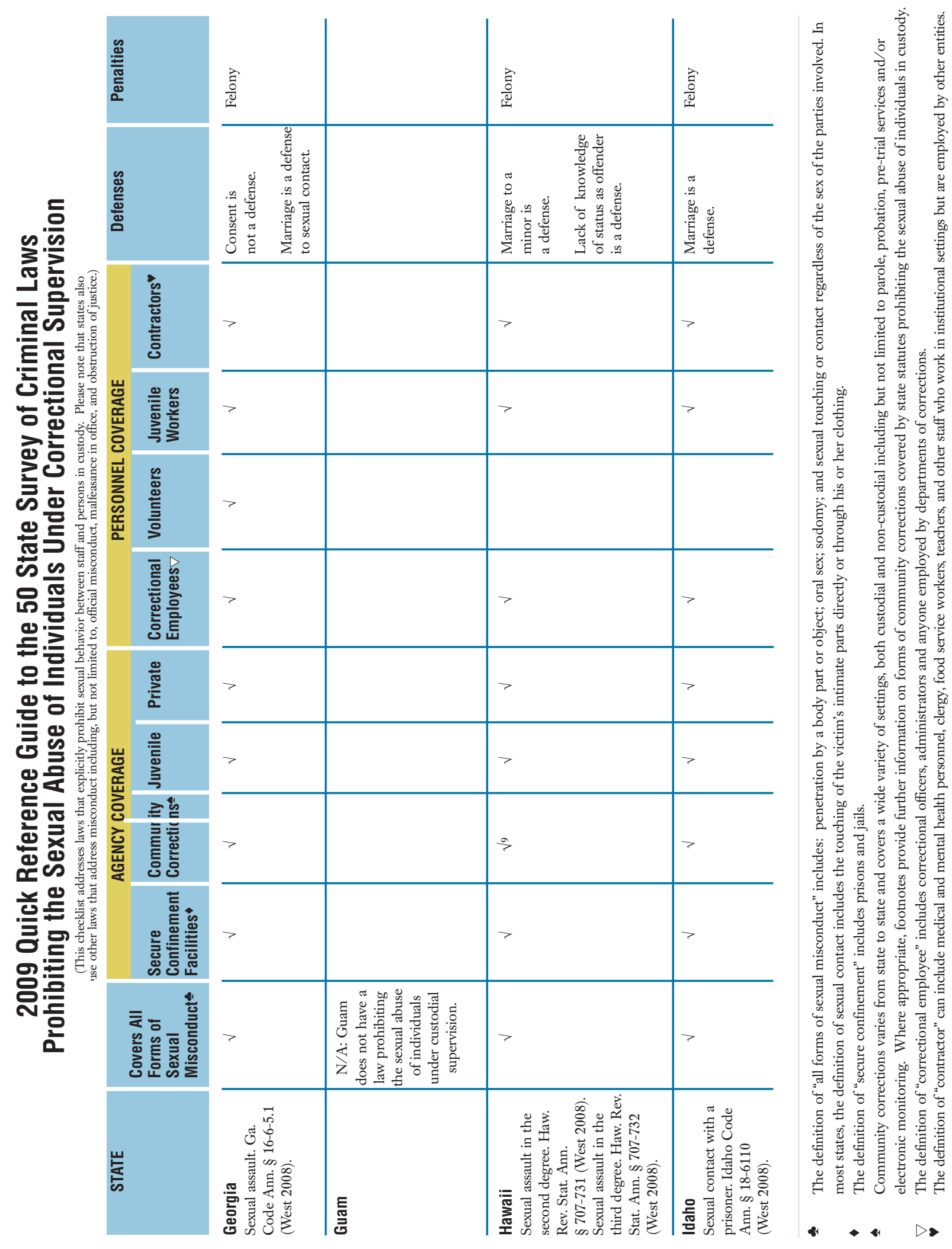




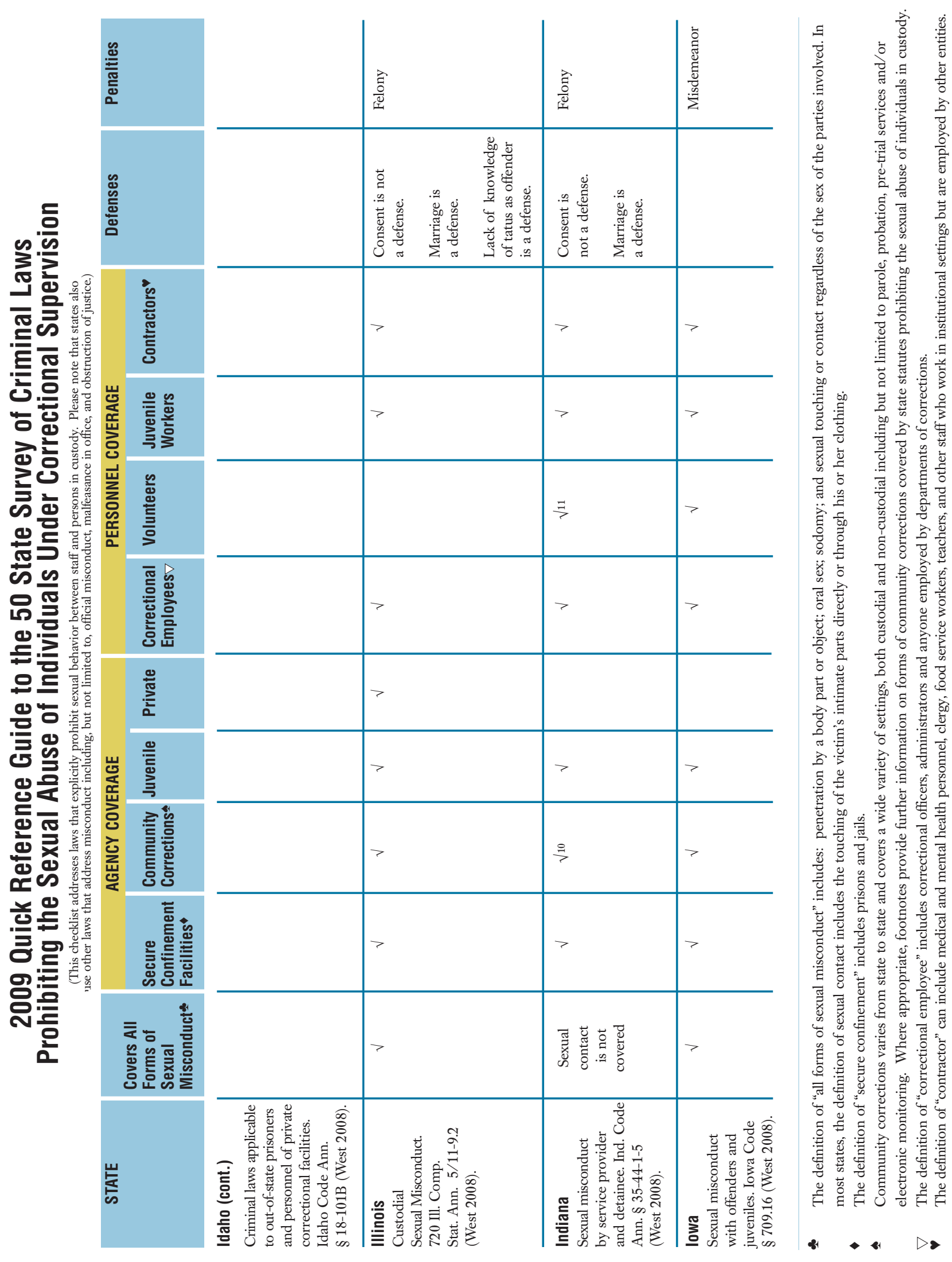




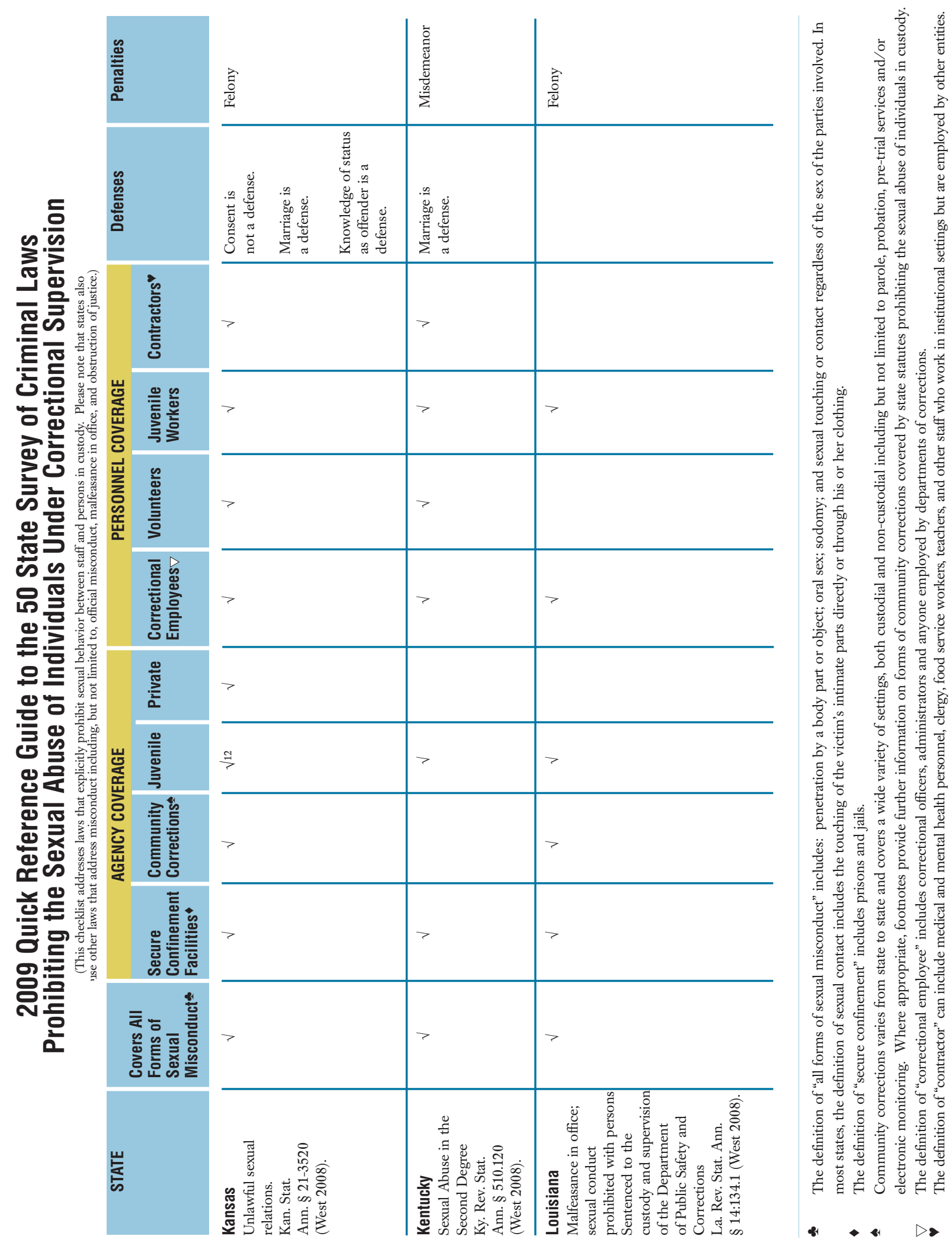




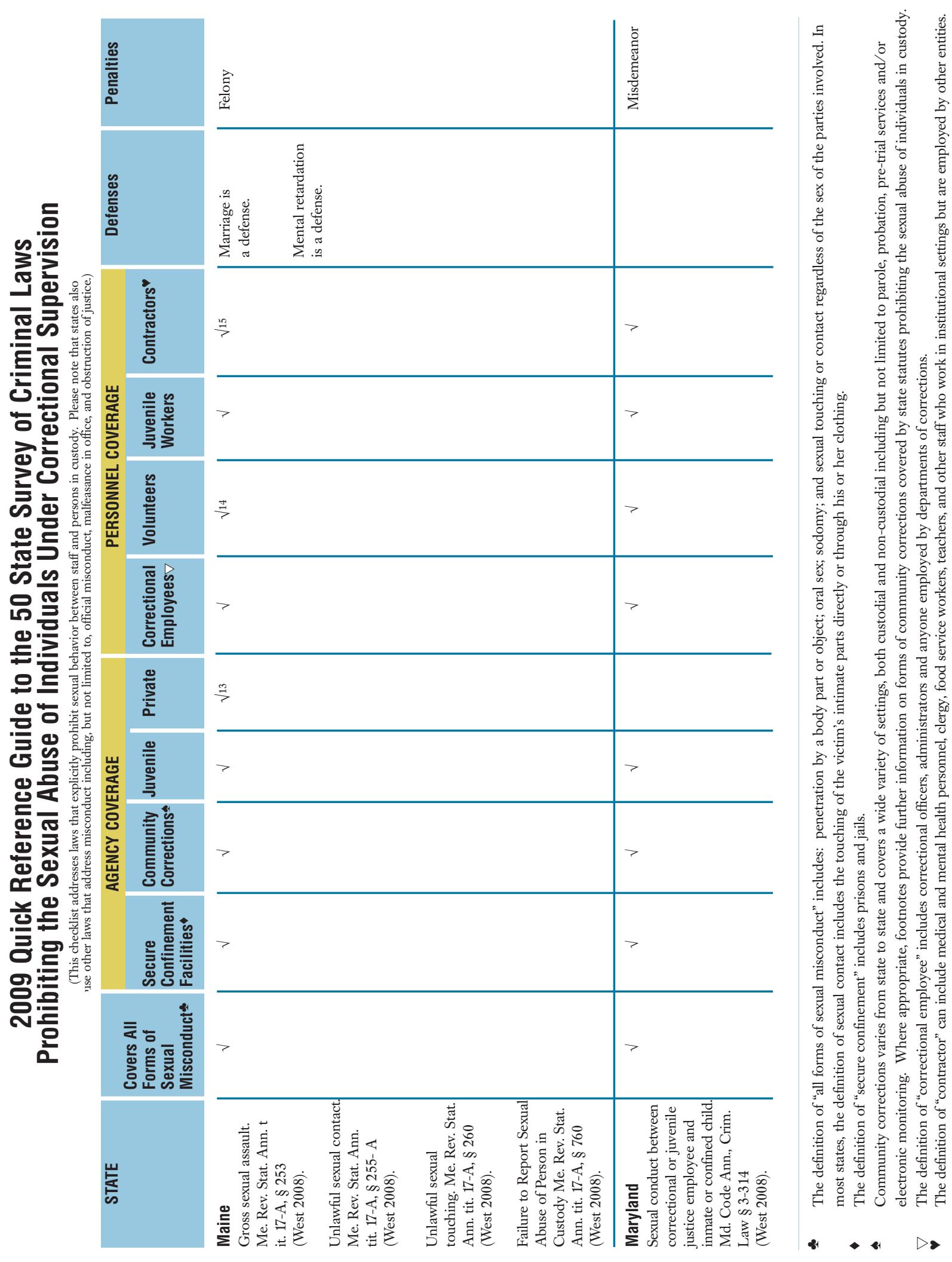




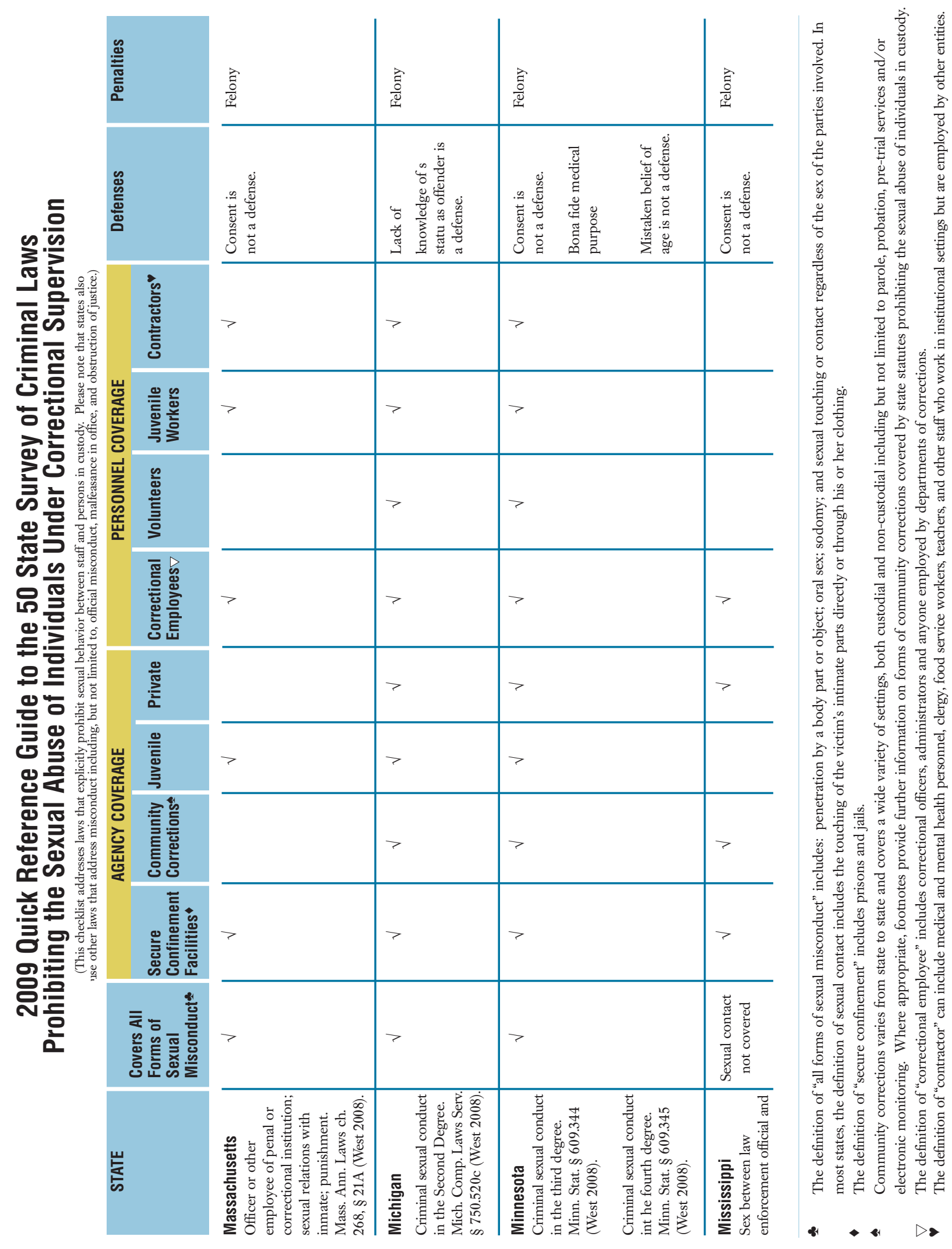




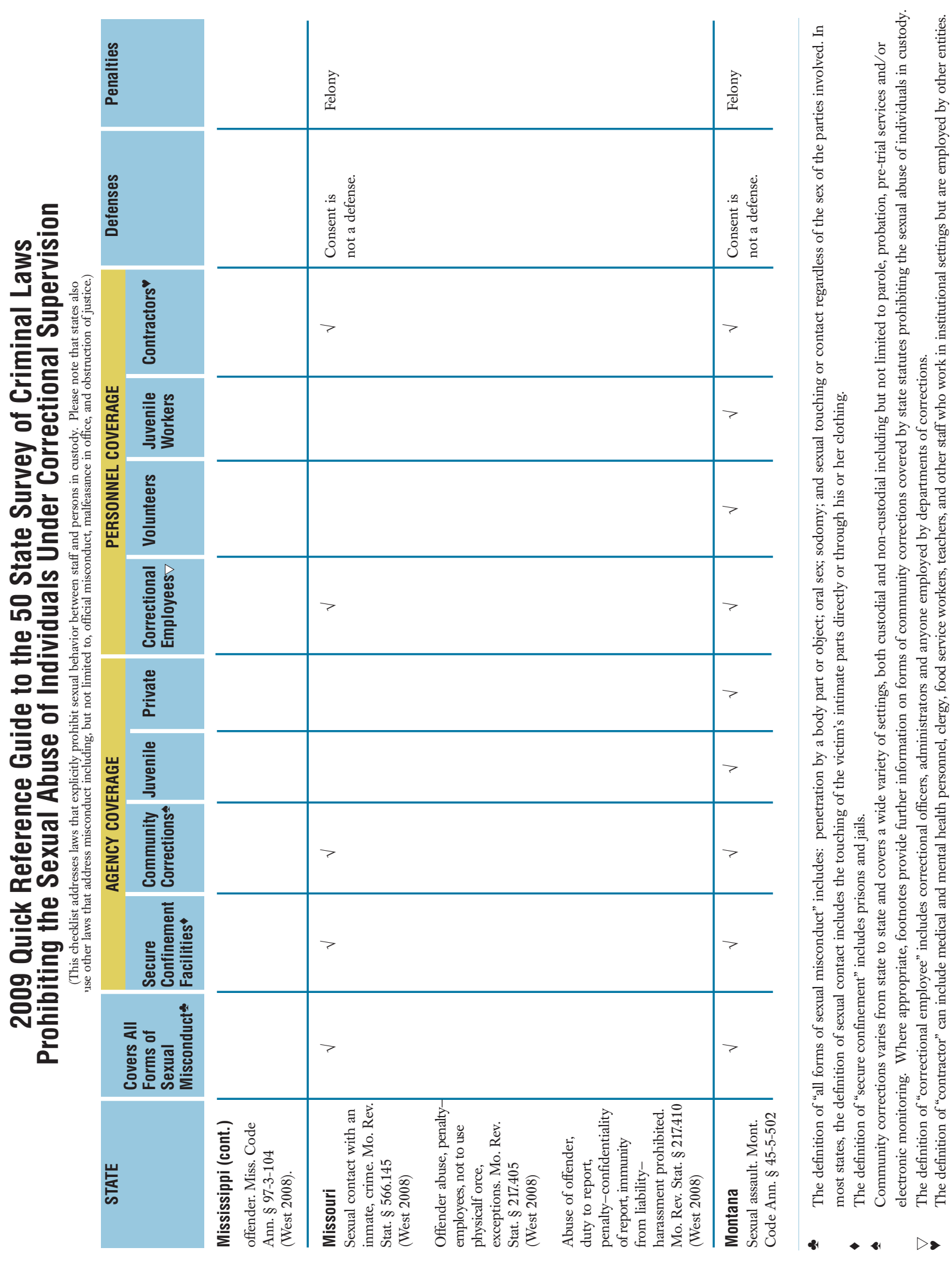




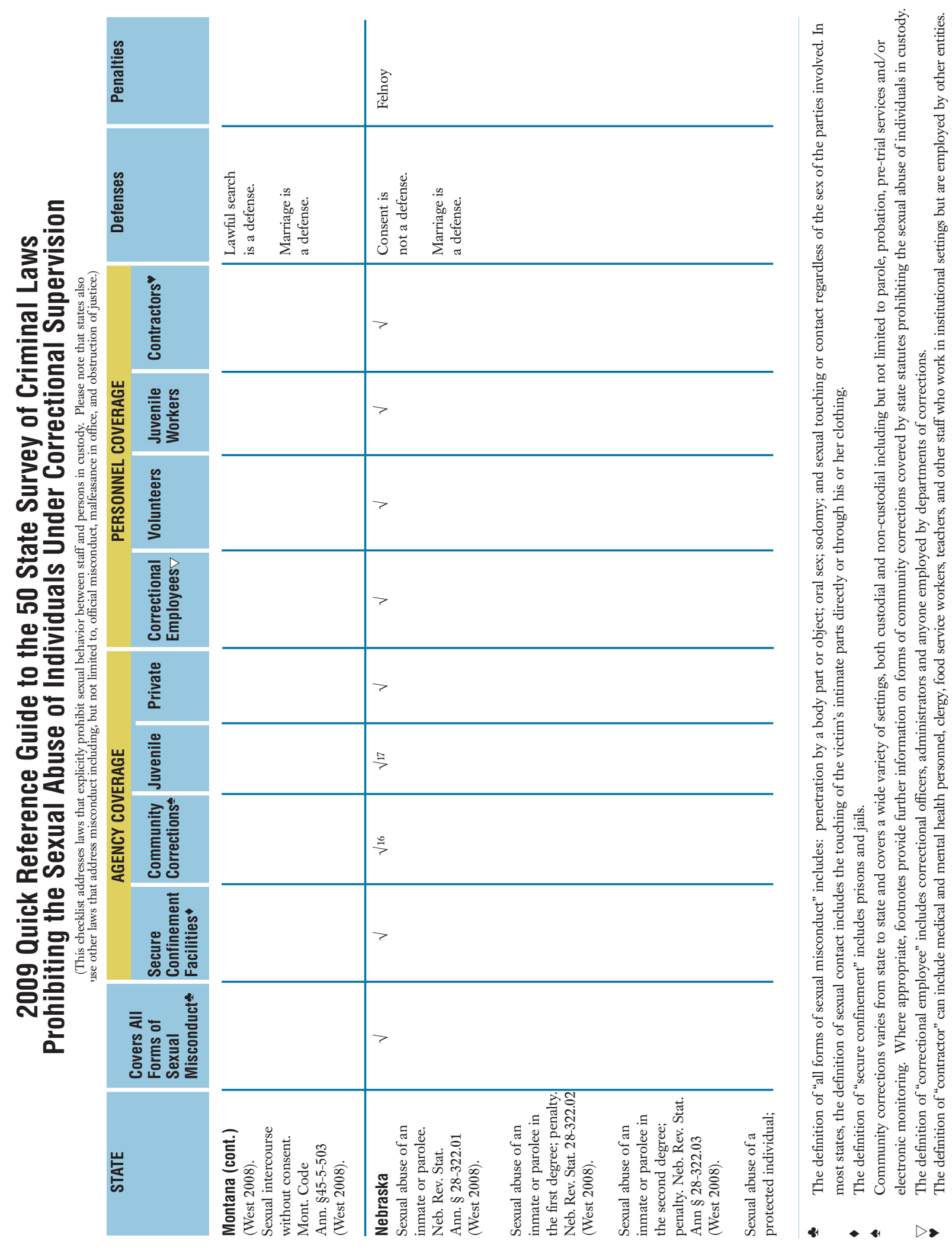




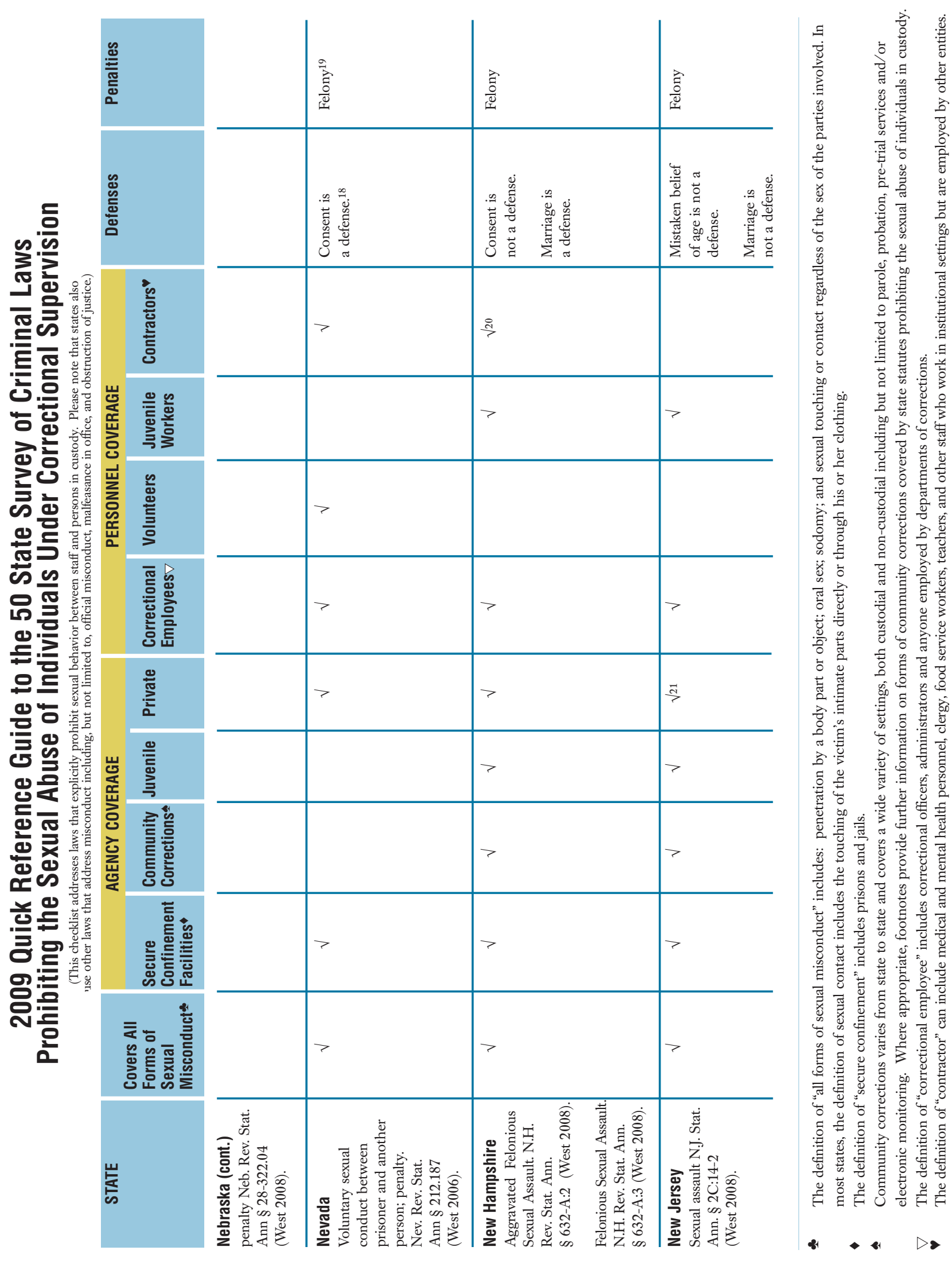




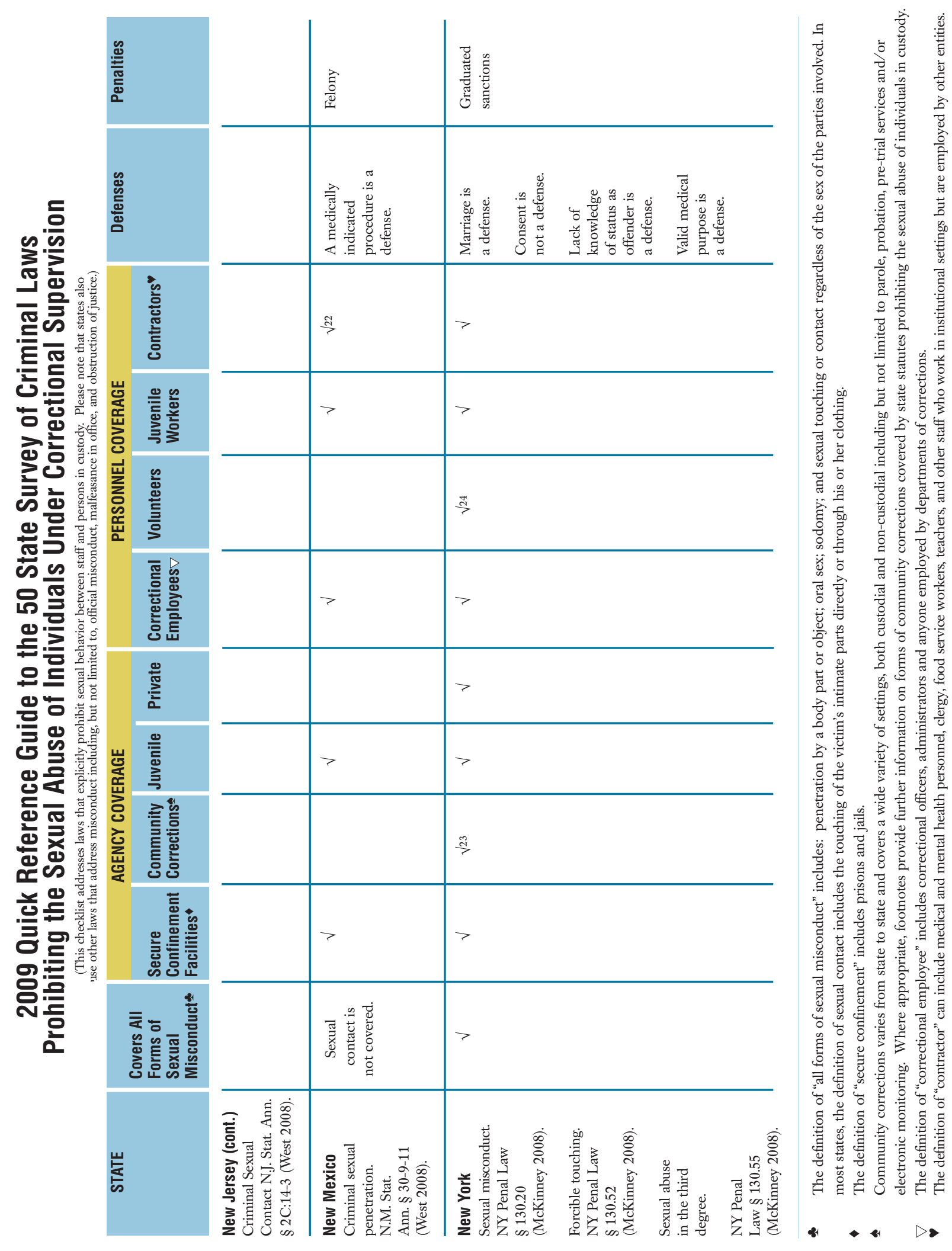




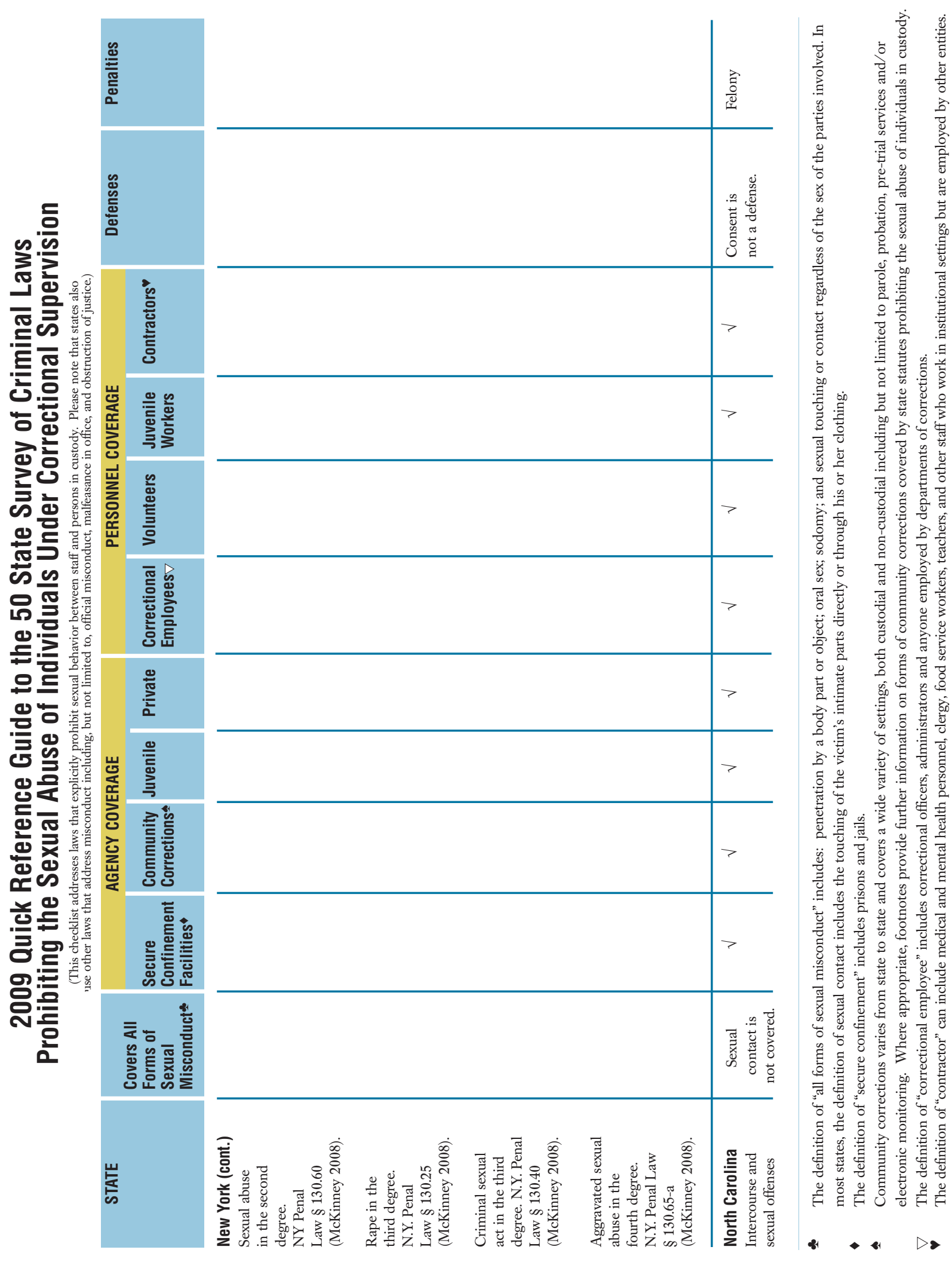




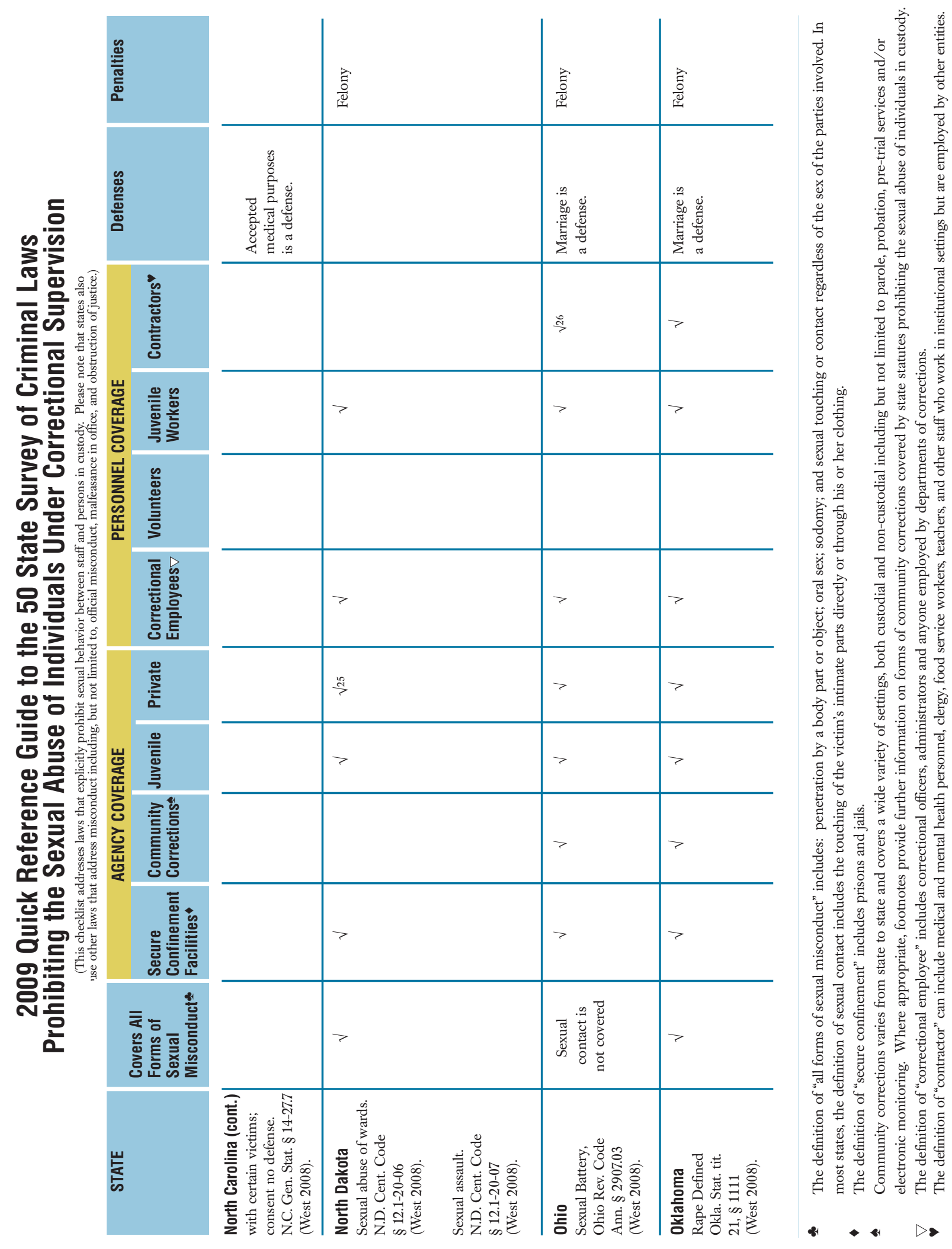




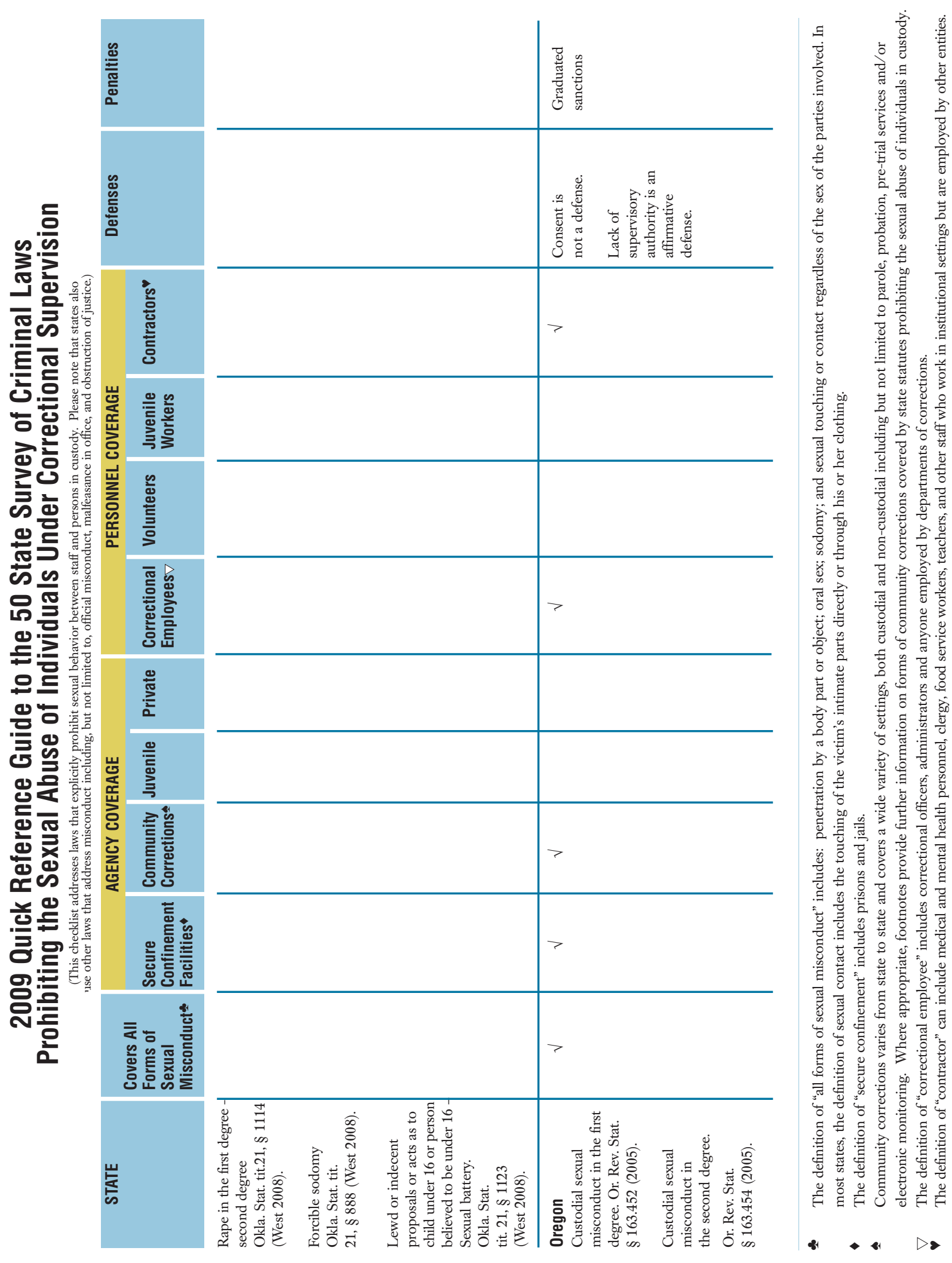




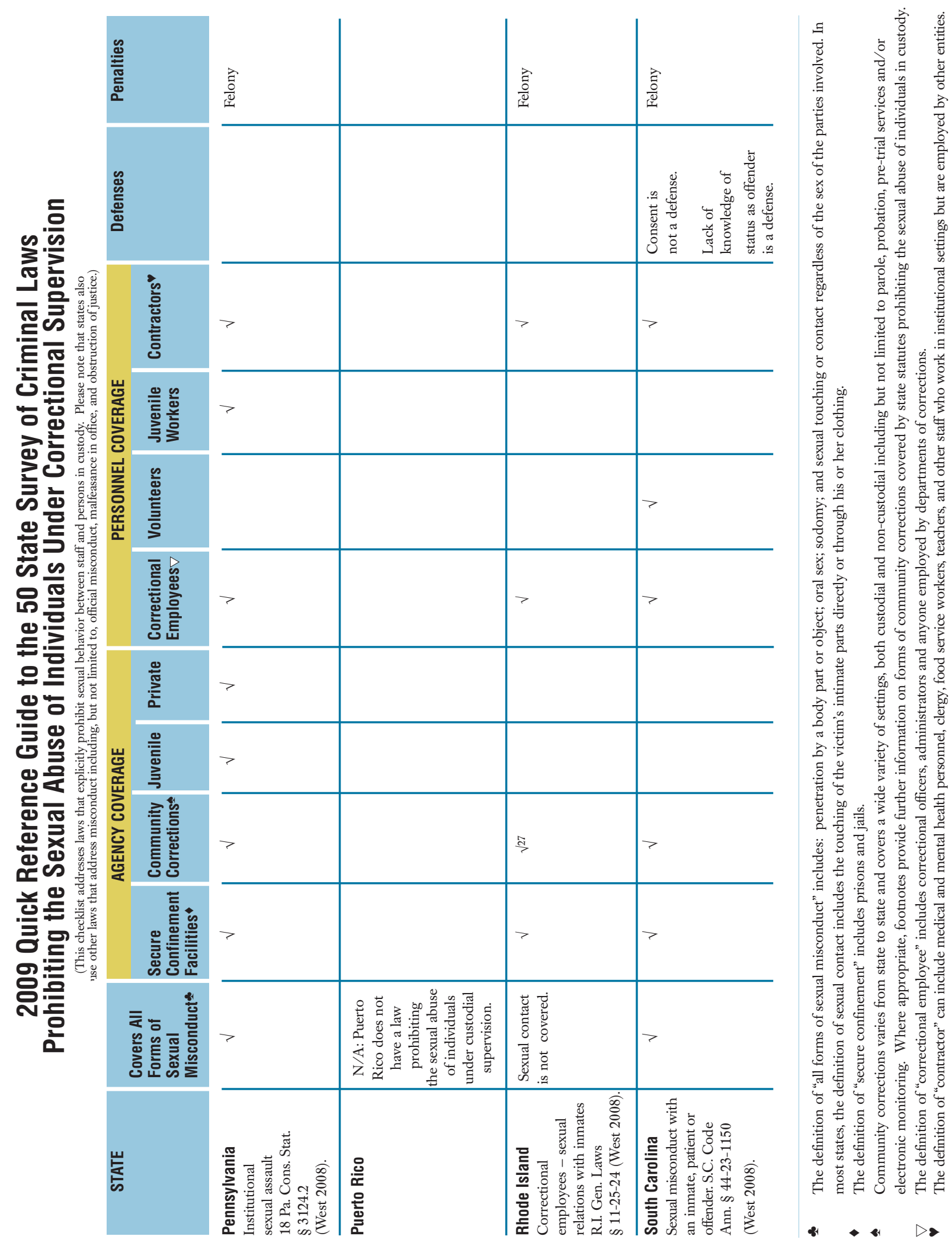




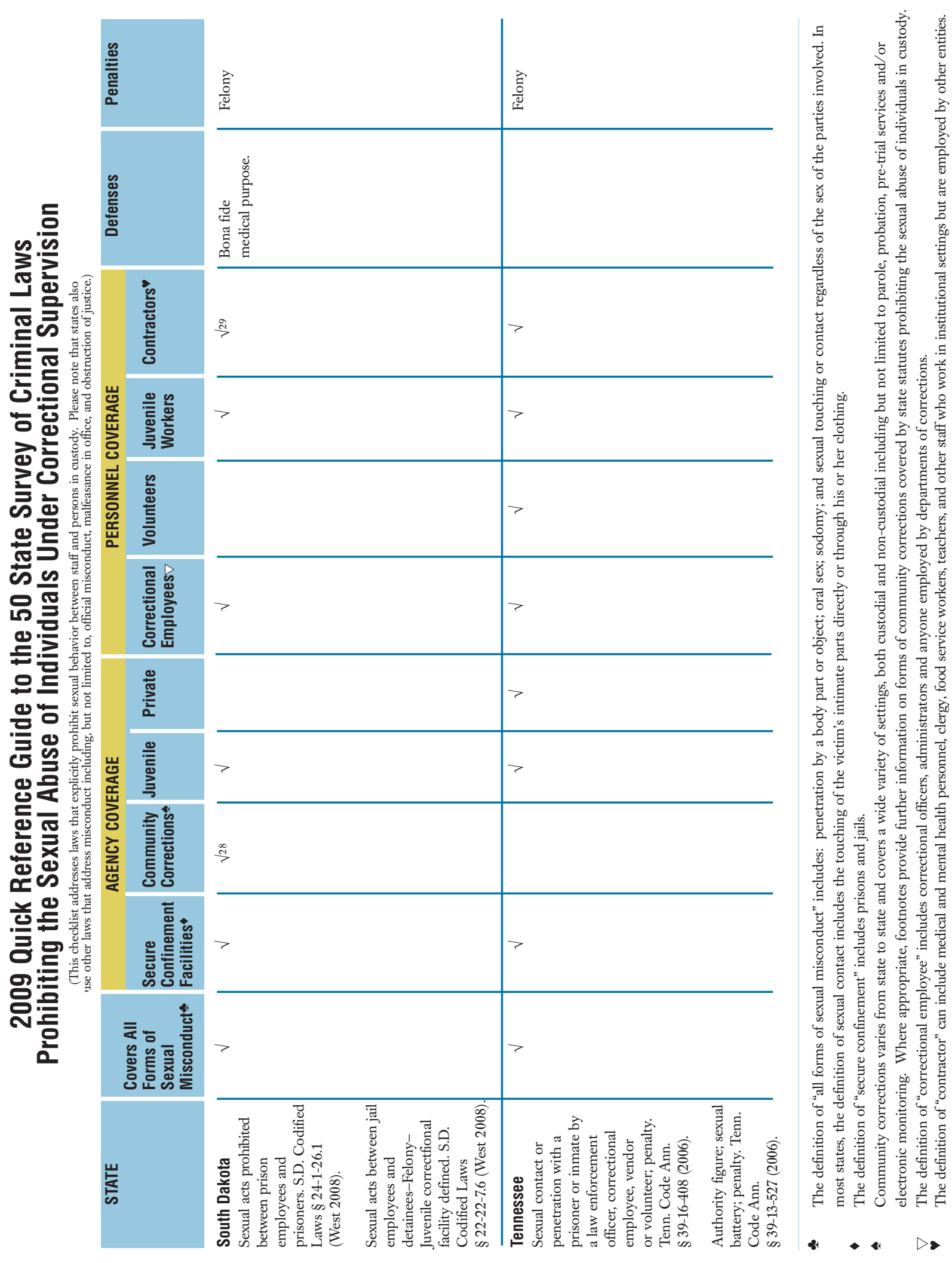




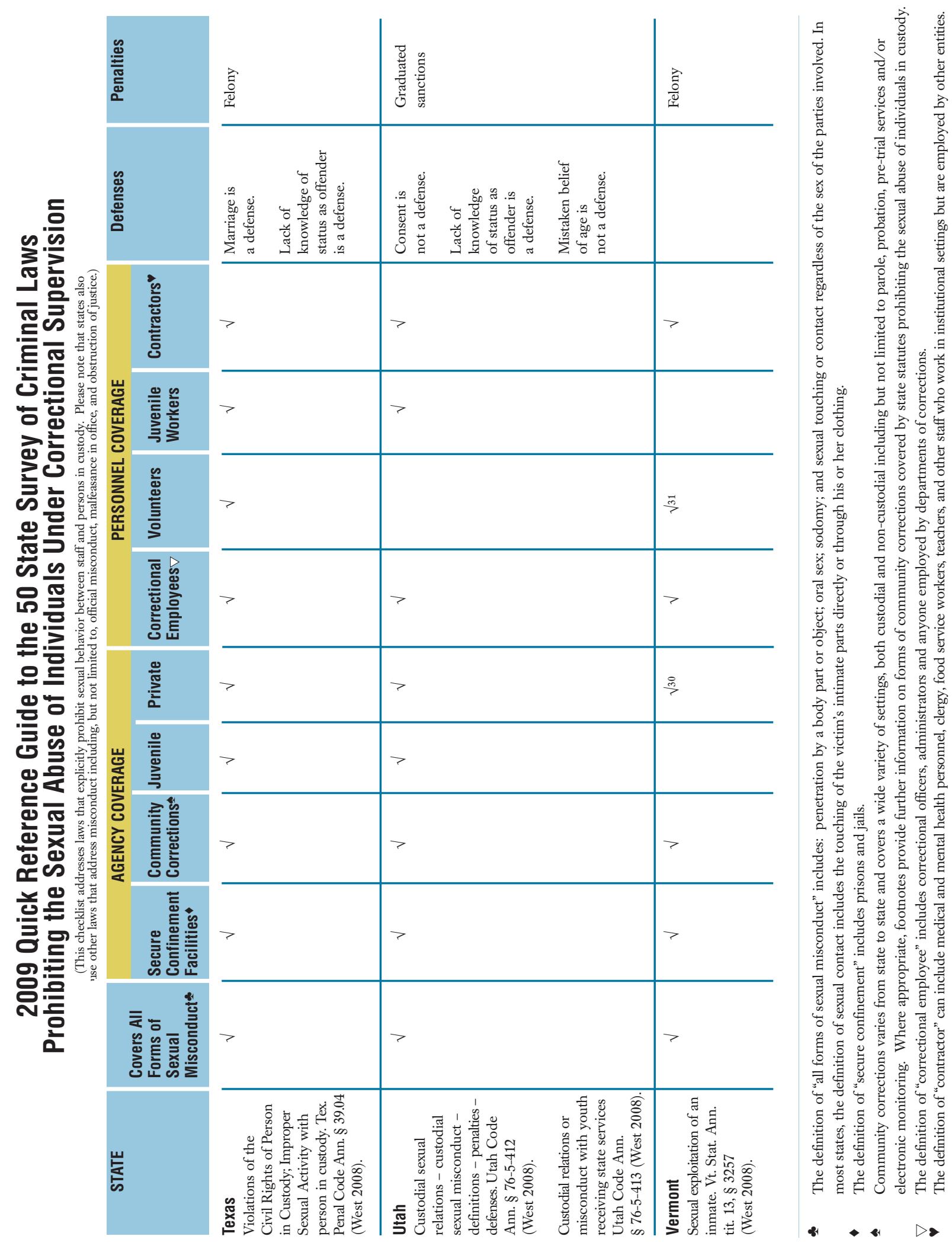




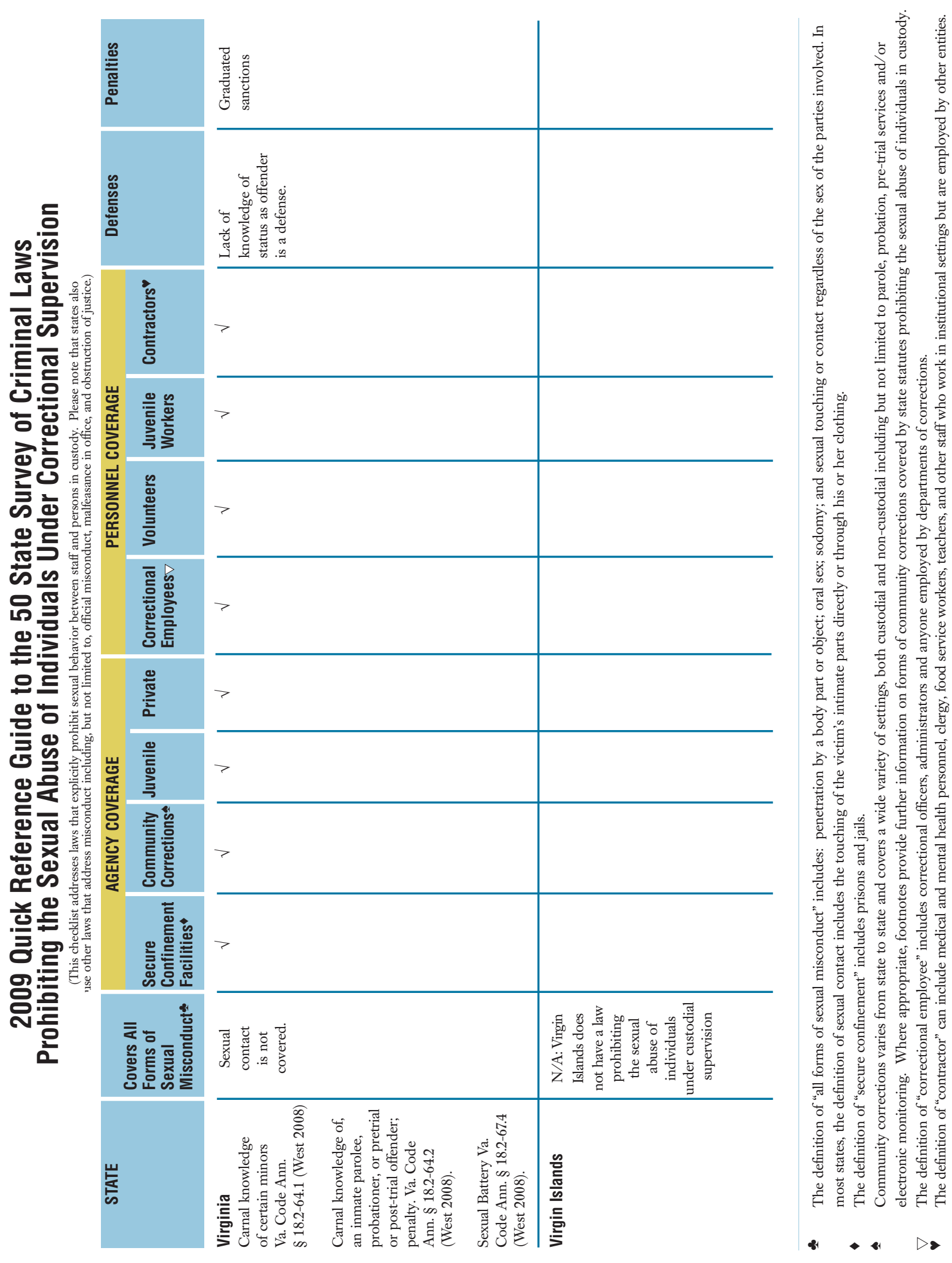




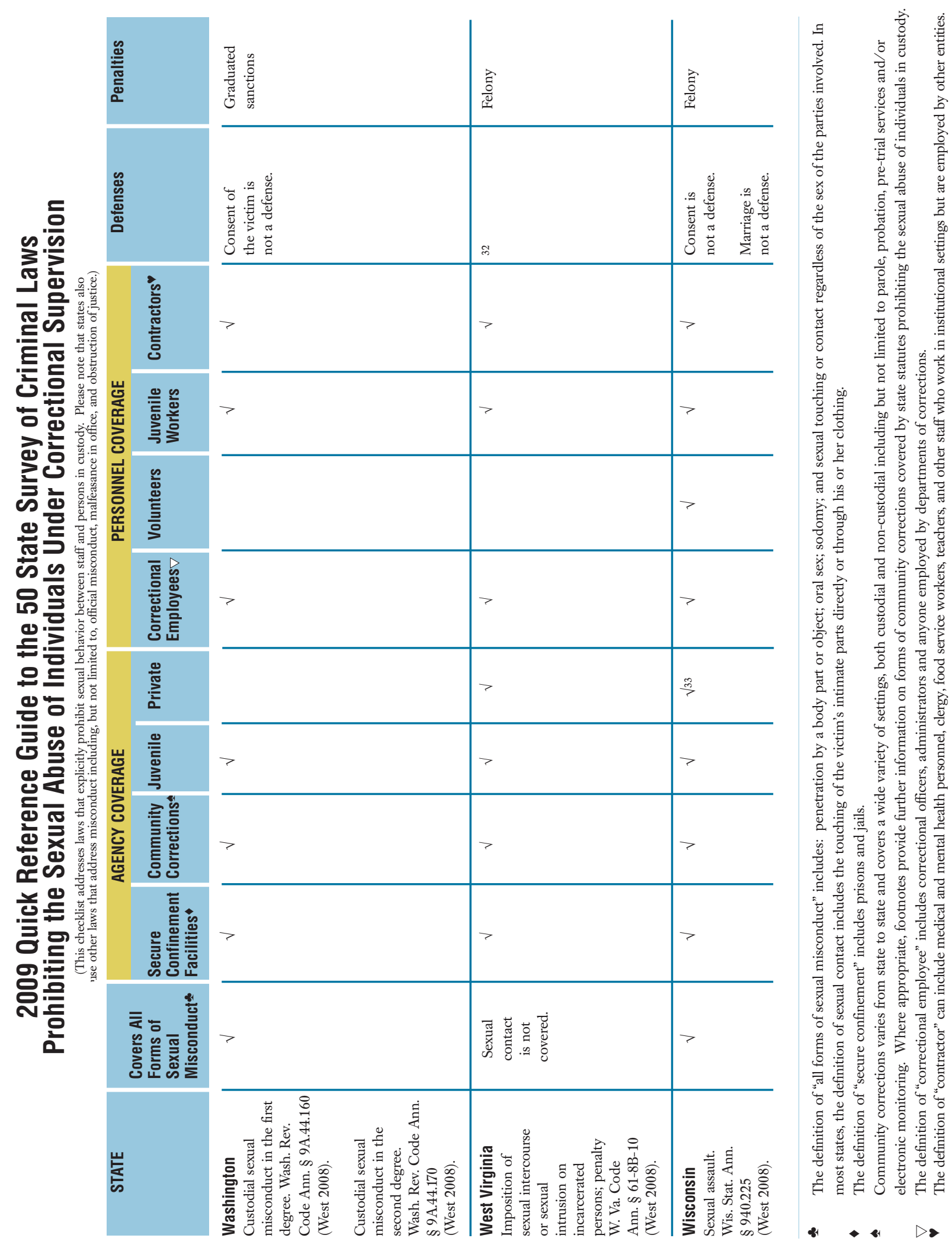




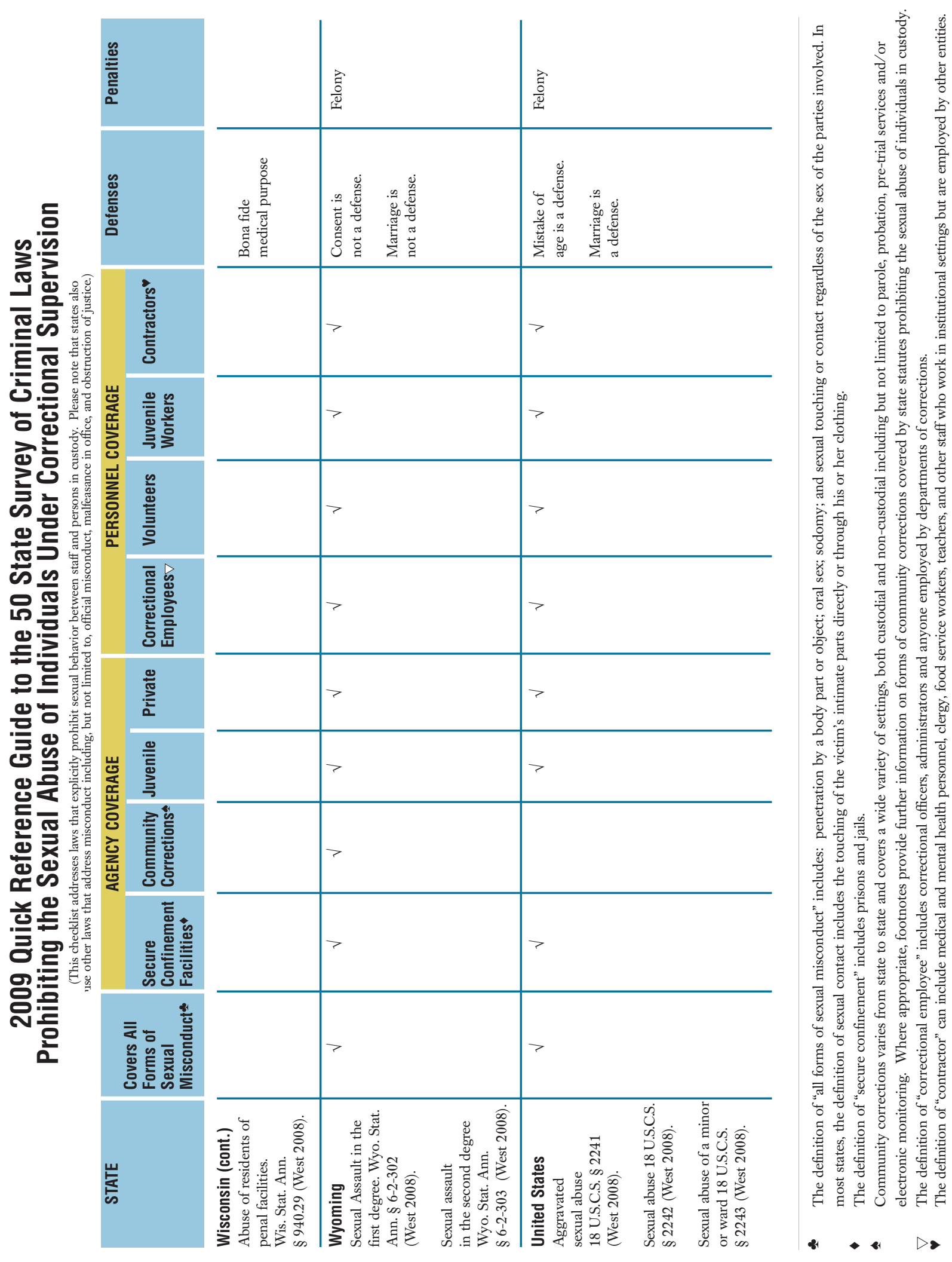




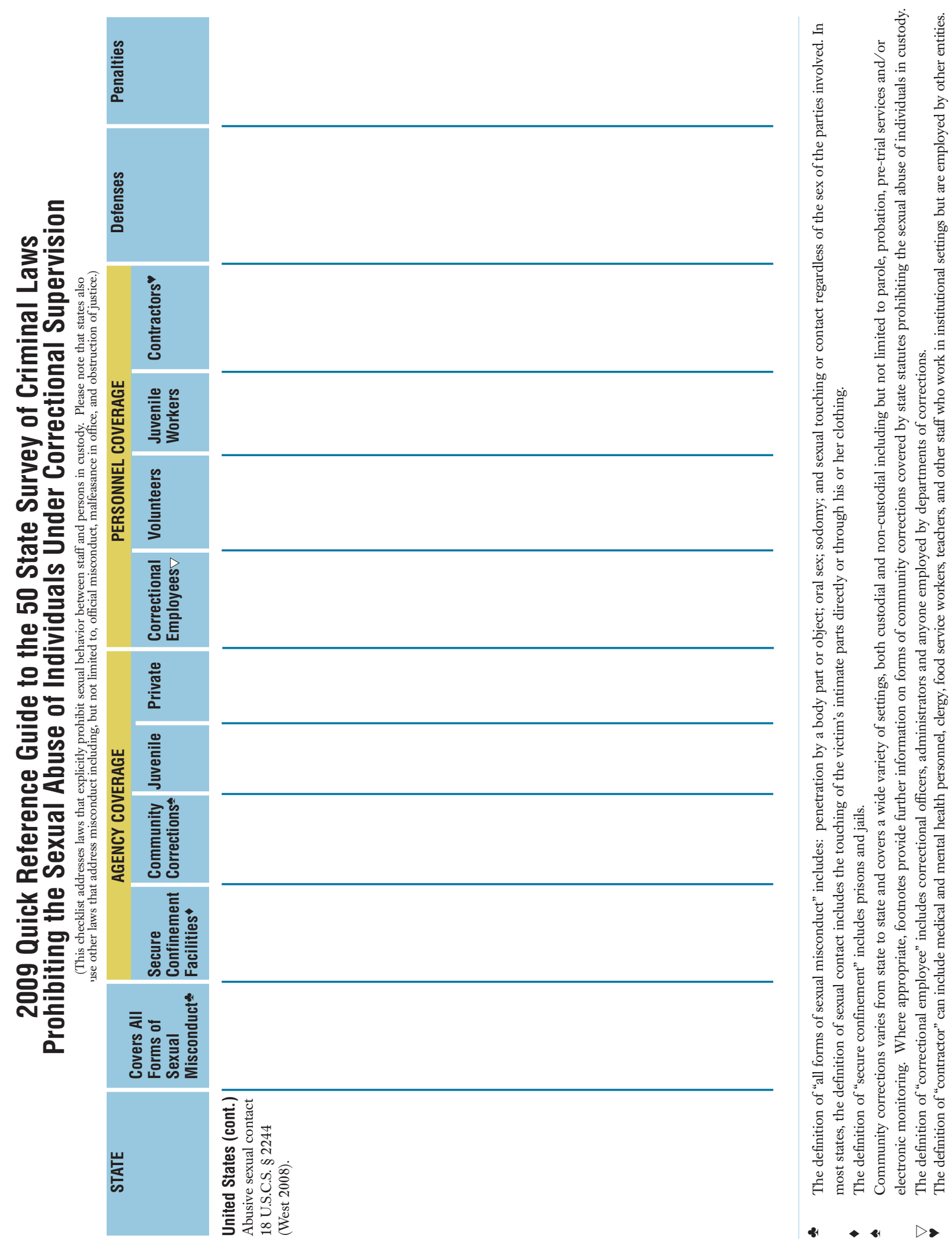



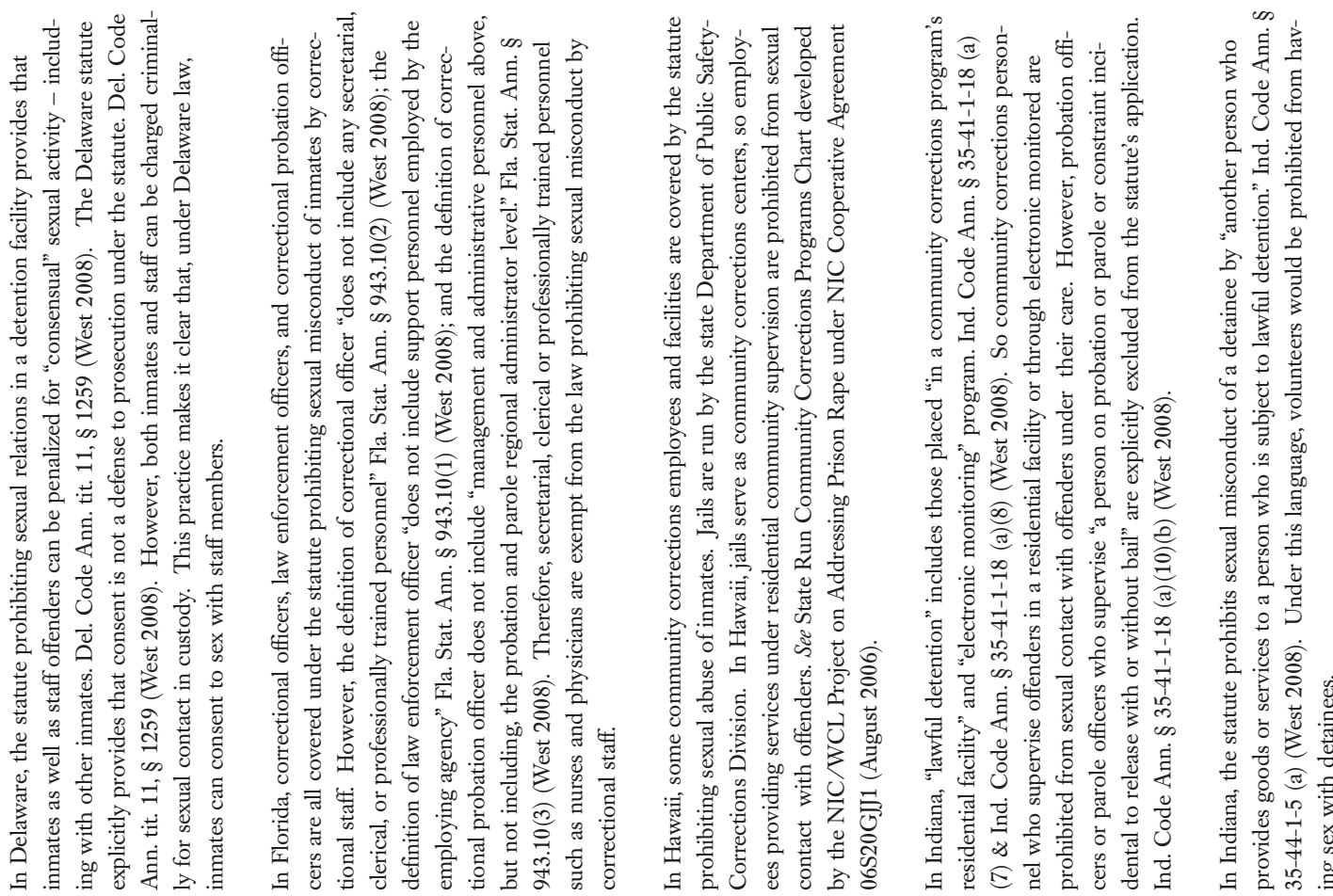

$N$
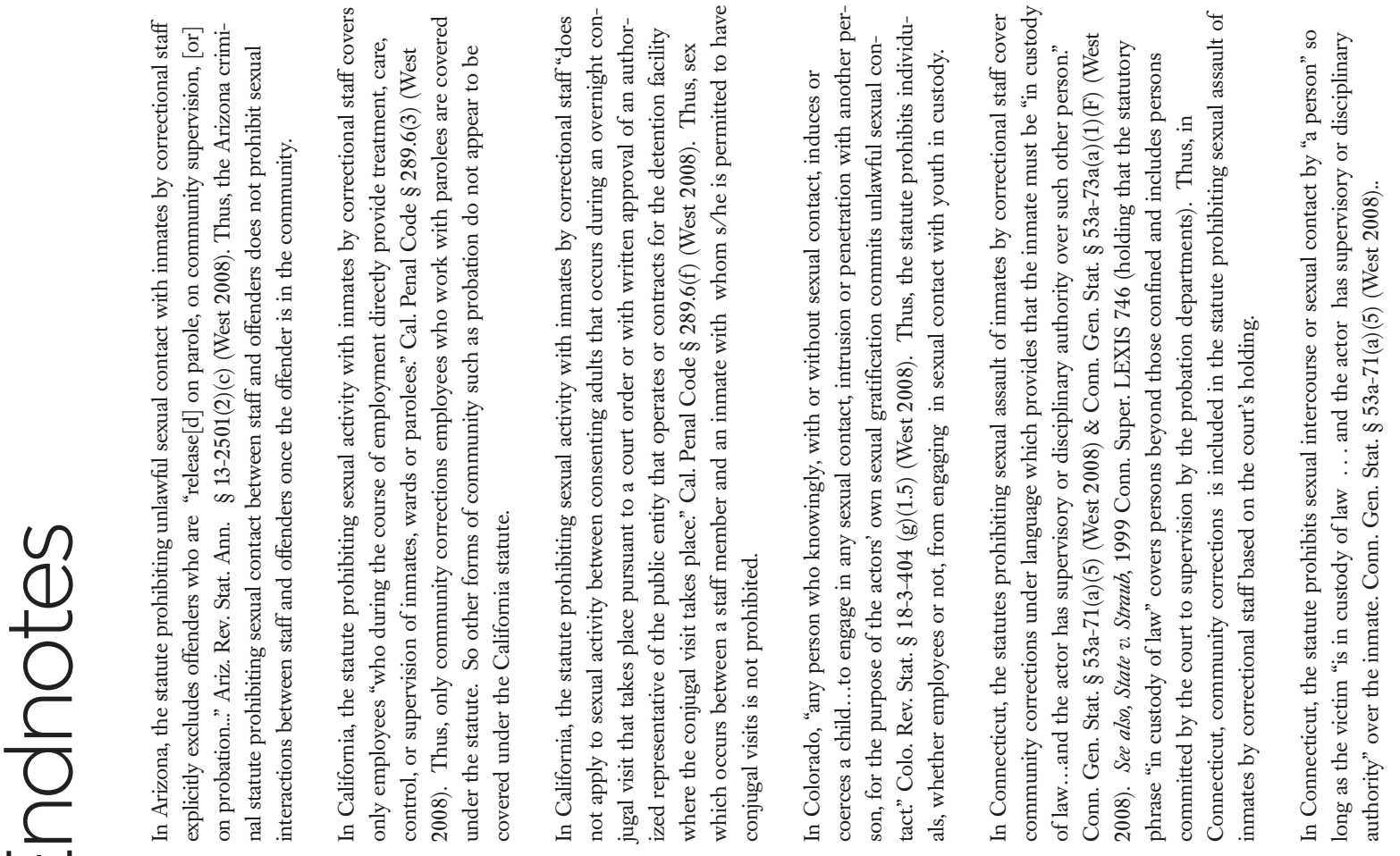

$$
\stackrel{ }{ }
$$$$
\dot{\exists}
$$ 


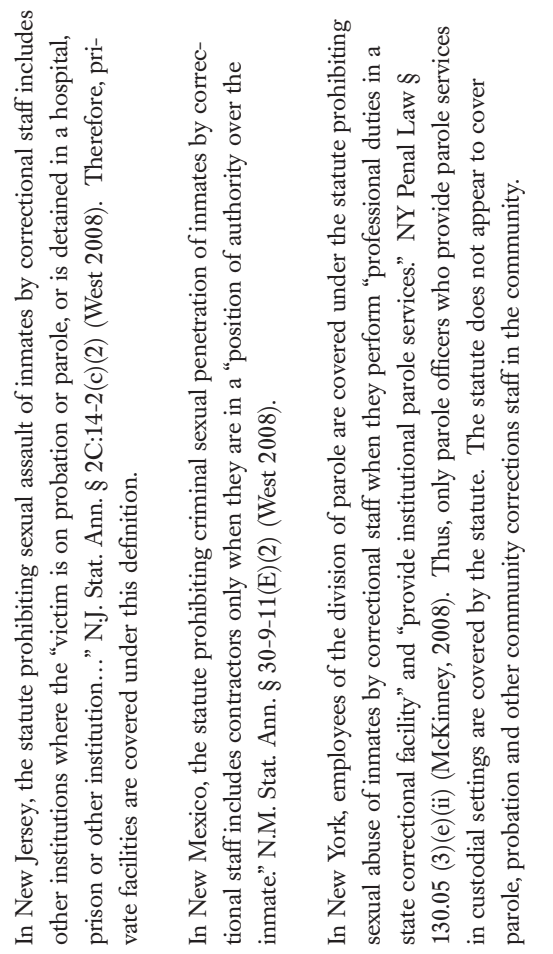

$\dot{4}$

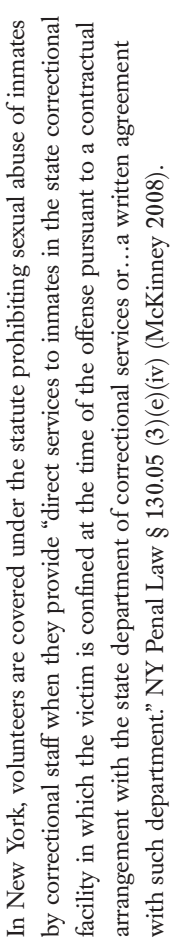

$\stackrel{\sim}{ }$

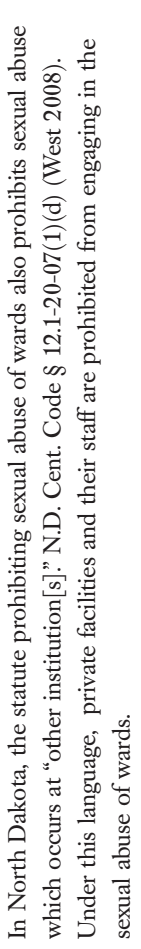

นู่

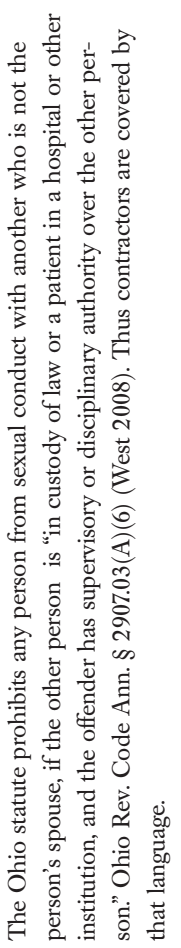

กั

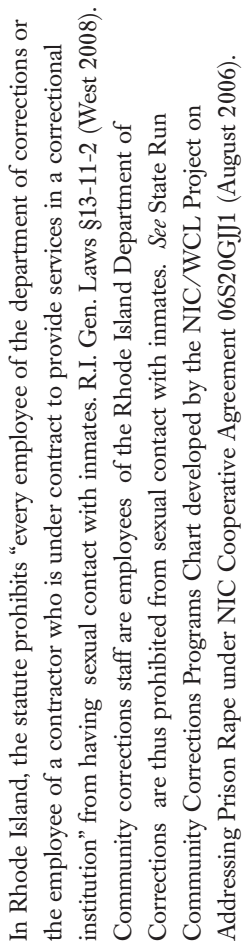

ล่

$\stackrel{\infty}{\sim}$
离高苞

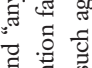

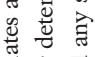

县 离

ㅎํㅇํㅇ

类

造造

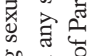

贯

릉

至

范

胥

起

踏

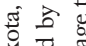

跣

छี हैं

品

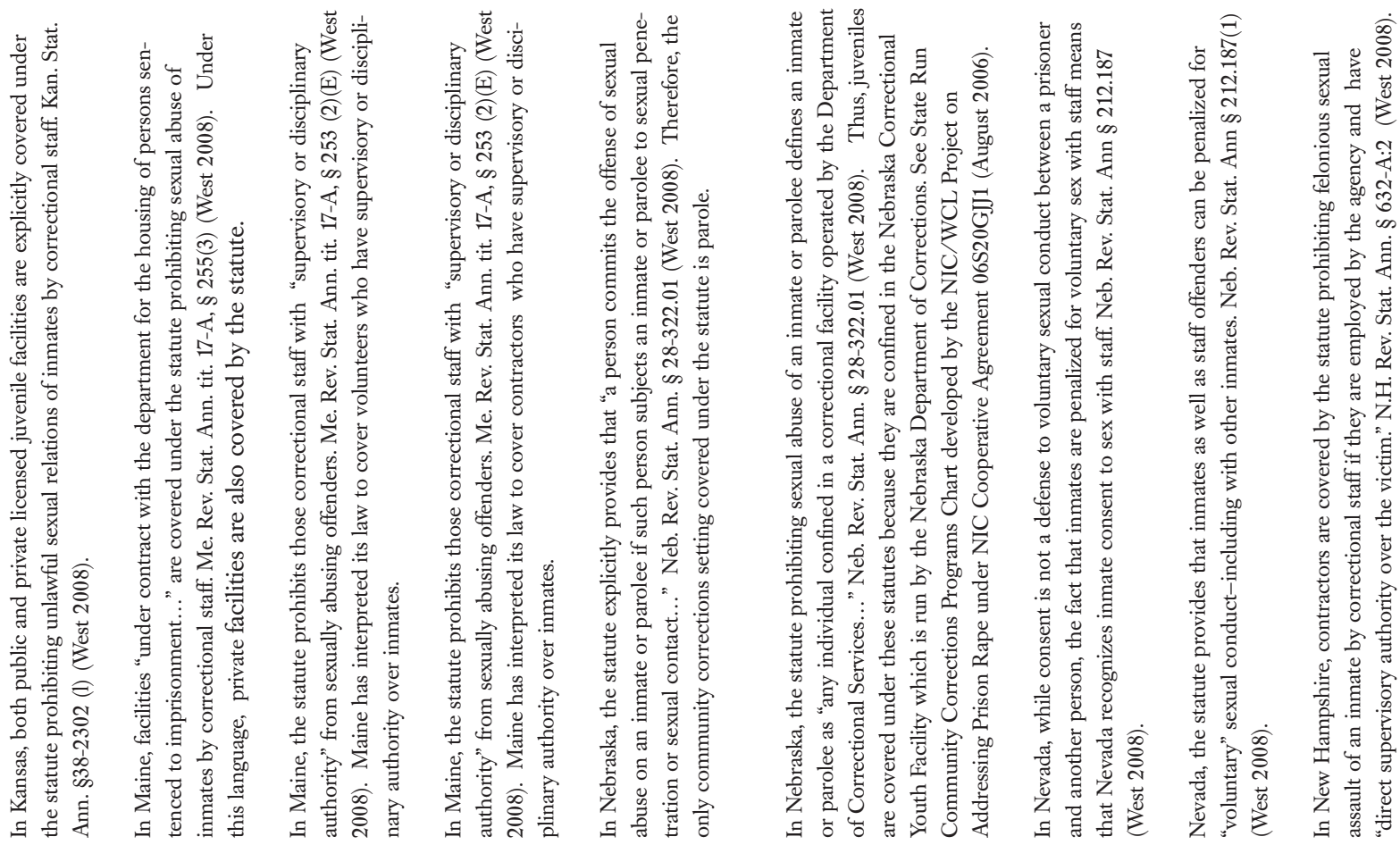

บ่

$\pm$

$\stackrel{2}{9}$

$\stackrel{1}{2}$

$\triangle$

$\stackrel{\infty}{\sim}$

$\stackrel{2}{2}$

ते 

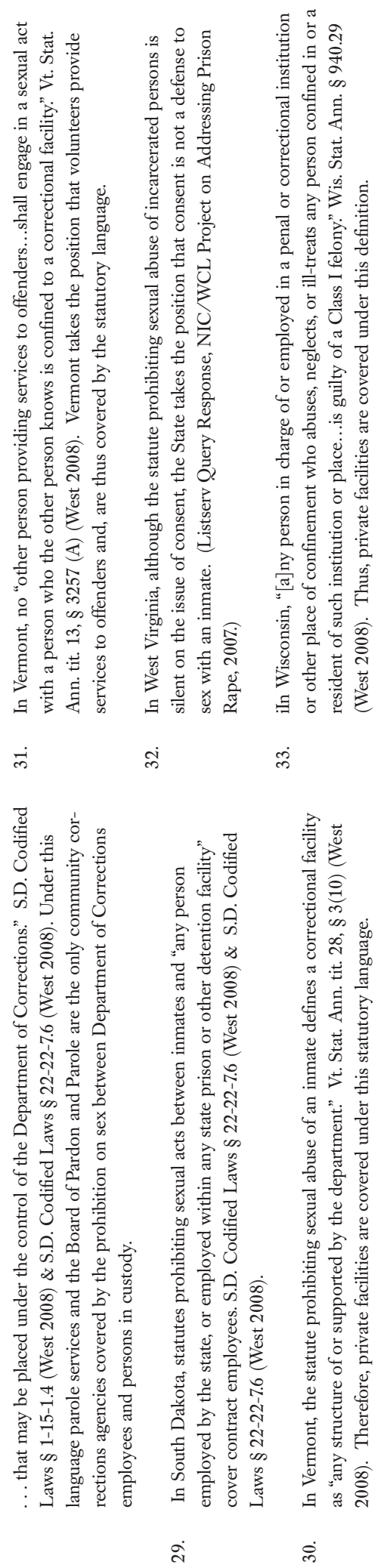
